\title{
Regional 3D geophysical investigation of the Sudbury Structure
}

\author{
Oladele Olaniyan ${ }^{1}$, Richard S. Smith ${ }^{1}$, and Bruno Lafrance ${ }^{1}$
}

\begin{abstract}
The 3D geologic and structural setting of the Sudbury Structure was predicted by an integration of surface and subsurface geologic data with 2.5D modeling of high-resolution airborne magnetic and gravity data using 3D GeoModeller software. Unlike other CAD-based 3D software, GeoModeller uses the field interpolator method, whereby contacts of rock units are assumed to be equipotential surfaces, whereas orientation data determine the gradient and direction of the surfaces. Contacts and orientation variables are cokriged to generate 3D continuous surfaces for each geologic unit. Our 3D geologic model was qualitatively evaluated by forward computing the predicted gravity response at $1 \mathrm{~m}$ above topography and by comparing this response to the measured gravity field. Large-scale structures within the Onaping Formation and Archean basement, which overlie and underlie the Sudbury Igneous Complex (SIC), respectively, were not the cause of the linear gravity high in the center of the Sudbury Structure. We suggested that the deformation of the initial circular SIC may have commenced under the Sudbury Basin due to the reversal of the normal faults related to the Huronian rift system during the Penokean orogeny, therefore resulting into a north verging fold at the base of the SIC in the south range. This new interpretation was consistent with the magnetic and gravity data and honoured most of the significant seismic reflectors in the Lithoprobe seismic sections.
\end{abstract}

\section{Introduction}

Exploration and mining of nickel and copper in offset dikes and embayments at the base of the Sudbury Igneous Complex (SIC) has been ongoing for more than a century, with the deepest producing mine now at a depth of approximately $2 \mathrm{~km}$. Exploration for ore bodies close to the surface is gradually becoming less economic and more difficult. Understanding the subsurface geology of the Sudbury Structure requires predicting its geologic and structural setting everywhere: Data from surface and shallow subsurface points must be extrapolated to the deeper subsurface. Multiple deformational episodes, together with limited subsurface geologic and geophysical information in most parts of the Sudbury Structure, make this task especially difficult. High-grade sulfide mineralization is indubitably present at greater depths, where it is likely controlled by preexisting and synimpact structures and impactbrecciated footwall rocks. However, exploration beyond depths of $500 \mathrm{~m}$ is very challenging because few geophysical exploration methods can be used to investigate sulfides at that depth. Seismic surveys, deep electrical methods, and borehole geophysical tools in deep boreholes could be used to detect ore zones, but these techniques are very expensive (Milkereit and Green, 1992; Polzer, 2000).
Recent advances in 3D modeling such as GoCad (Caumon et al., 2009), GeoModeller (Lane and Guillen, 2005), and Encom ModelVision and inversion codes such as those from the University British Colombia (Williams, 2006) have enhanced the capability to develop a realistic model that projects the known $2 \mathrm{D}$ surface geologic information to depth or to develop a subsurface physical property distribution map that is consistent with the geophysical data. These advancements, together with seismic and potential field data sets, have been incorporated in the subsurface bedrock investigation of large impact structures around the world, such as the Chicxulub structure in Mexico and the Vredefort Dome in South Africa (Galdeno et al., 2008; Veermeesch and Morgan, 2008). The Sudbury Structure, first proposed by Dietz (1964) and now broadly accepted as an impact structure (Pye et al., 1984), has been largely eroded leaving only relics of an interpreted central peak-ring crater (Deutsch et al., 1995; Spray et al. 2004), buried under a thick pile of sedimentary rocks of the Whitewater Group. A better understanding of the subsurface geology at depth using new 3D modeling and inversion codes will further assist in the prediction of preexisting structures that might act as controls or traps for mineralization, thereby defining deeper prospective zones for future exploration.

\footnotetext{
${ }^{1}$ Laurentian University, Department of Earth Sciences, Sudbury, Ontario, Canada. E-mail: ox_olaniyan@laurentian.ca; rssmith@laurentian.ca; blafrance@laurentian.ca.

Manuscript received by the Editor 5 September 2014; revised manuscript received 15 February 2015; published online 22 April 2015. This paper appears in Interpretation, Vol. 3, No. 2 (May 2015); p. SL63-SL81, 14 FIGS., 1 TABLE.

http://dx.doi.org/10.1190/INT-2014-0200.1. @ 2015 Society of Exploration Geophysicists and American Association of Petroleum Geologists. All rights reserved.
} 
A Lithoprobe seismic transect was completed across the Sudbury Structure in 1992. Two seismic lines were merged to provide a full section across the SIC (Milkereit and Green, 1992). Interpretations of the full section differ because some reflectors were ill-defined due to seismic noise, a lack of impedance contrast between units, and their subvertical dips (Milkereit and Green, 1992; Card and Jackson, 1995; Wu et al., 1995; Olaniyan et al., 2014). The interpreted subsurface geometry of the merged Lithoprobe section has been used to further constrain 2D magnetic and gravity sections across the SIC (Hearst et al., 1994; McGrath and Broome, 1994). Olaniyan et al. (2014) highlight the major challenges in the merging of these two lines as modeling along an east-west line shows changes in depth and thickness of lithologic units and in the spatial location of the SICfootwall contact. The variations in the SIC lithologic units and the location of the footwall contact along the latitude from the eastern end of the SIC to the western end introduce some inconsistencies into the contacts earlier defined by the Milkereit merged Lithoprobe sections (Olaniyan et al., 2013).

Previous work (Gupta et al., 1994; Hearst et al., 1994; McGrath and Broome, 1994) and recent qualitative geophysical interpretation of high-resolution airborne geophysical data (Olaniyan et al., 2013) have not provided an adequate explanation of some extensive geophysical anomalies observed within the SIC (Figure 1a and 1b). These include (1) the abrupt discontinuity of the high magnetic intensity in the north range around the Sandcherry Fault, (2) the low magnetic intensity zone that extends from the north range to the south range at their junction with the east range, and (3) the linear gravity high observed in the center of the Sudbury Structure. The latter trends east-southeast from the western part of the north range to the south part of the east range. Gupta et al. (1994) investigate this gravity high and conclude that it is not related to the any of the SIC rocks, but it is more likely due to deeper mafic intrusions. However, their study does not consider the possibility of northward-directed thrusting and folding at the base of the SIC (Olaniyan et al., 2014).

Explaining these anomalies requires understanding the deep subsurface geologic architecture of the Sudbury Structure. In this study, a 3D geologic model is constructed by integrating six $2.5 \mathrm{D}$ models of highresolution airborne gravity and magnetic profiles (Figure $1 \mathrm{a}$ and $1 \mathrm{~b}$ ). Two models that were previously calculated by Olaniyan et al. (2014) (D-D $\mathrm{D}^{\prime}$ and $\mathrm{E}-\mathrm{E}^{\prime}$ ) are combined with four new models (A-A', B-B', C-C ${ }^{\prime}$, and F-F $\mathrm{F}^{\prime}$ ) across the SIC for this report.

\section{Geophysical setting of the Sudbury Structure}

The Sudbury Structure straddles the Archean Superior craton and the overlying Southern Province in Ontario, Canada. It comprises (1) the SIC - A differentiated igneous complex consisting, from bottom to top, of sublayer, norite, quartz gabbro, and granophyre; (2) an overlying 2900-m-thick sedimentary and breccia sequence of the Whitewater Group comprising, from bottom to top, the Onaping, Onwatin, and Chelmsford Formations; and (3) the impact-brecciated footwall rocks below the SIC. A more detailed description of the geologic setting of the Sudbury Structure has been summarized in previous papers by Naldrett et al. (1970), Dressler (1984), Pye et al. (1984), Rousell (1984), Spray et al. (2004), Riller (2005), and Ames and Farrow (2007).

The SIC has an elliptical shape with a long axis of $60 \mathrm{~km}$ and a short axis of $28 \mathrm{~km}$. Several magnetic and gravity anomalies are associated with the exposed rim of the SIC (Figure 1a and 1b). On a regional scale, these elliptical geophysical anomalies are superimposed on a broader geophysical response of approximately $350 \mathrm{~km}$ in length, which extends from Elliot Lake to the west, through Sudbury, then to Englehart to the east (Gupta et al., 1994). This regional anomaly is interpreted to be related to a paleocontinental margin of the Archean Superior Province overlain by deformed and metamorphosed Huronian supracrustal rocks of the Southern Province. There is a zone of high magnetic intensity approximately $10 \mathrm{~km}$ northeast of the SIC that has been interpreted to be related to the Superior-Southern Province boundary and well defined by banded iron formation. Other sources of high magnetic intensity in the Sudbury Structure include the basement Levack Gneiss Complex (LGC) in the north range, SIC norite and quartz gabbro, and younger northeast-trending olivine diabase dykes. The SIC's norite and quartz gabbro layers are relatively dense and have an average density of 2.81 and $2.88 \mathrm{~g} / \mathrm{cm}^{3}$ (Gupta et al., 1994; McGrath and Broome, 1994). These rocks together with the dense LGC and the sulfide-bearing sublayer contribute to the local elliptical gravity high around the rim of the SIC.

\section{Outline of methodology \\ Magnetic and gravity data 2.5D modeling and assumptions}

Magnetic data used in this study were extracted along the six profiles (Figure 1a and $1 \mathrm{~b}$ ) from a new regional compilation (Olaniyan et al., 2013), which brings together data collected in more than 40 different surveys in a single database (courtesy Sudbury Integrated Nickel Operations and Wallbridge Mining). The resolution of the gridded magnetic data varies from $20 \mathrm{~m}$ within the SIC to $50 \mathrm{~m}$ in a $10-\mathrm{km}$-wide area to the north of the SIC. Airborne gravity data acquired at 90-m flight height and 200-m line spacing were provided by Vale for selected profiles. Regional gravity data used in this study include the low-resolution GSC free-air data of approximately 2000-m cell size. Free-air gravity data are used in the interpretation so that topographic variation related to lithologic boundaries can be resolved in the model. No numerical filtering or regional-residual separation was applied prior to extracting the data because the deeper geologic setting of the Sudbury Structure is interpreted from the longer wavelength responses. 
a)

2.5-D profile lines on the total magnetic field

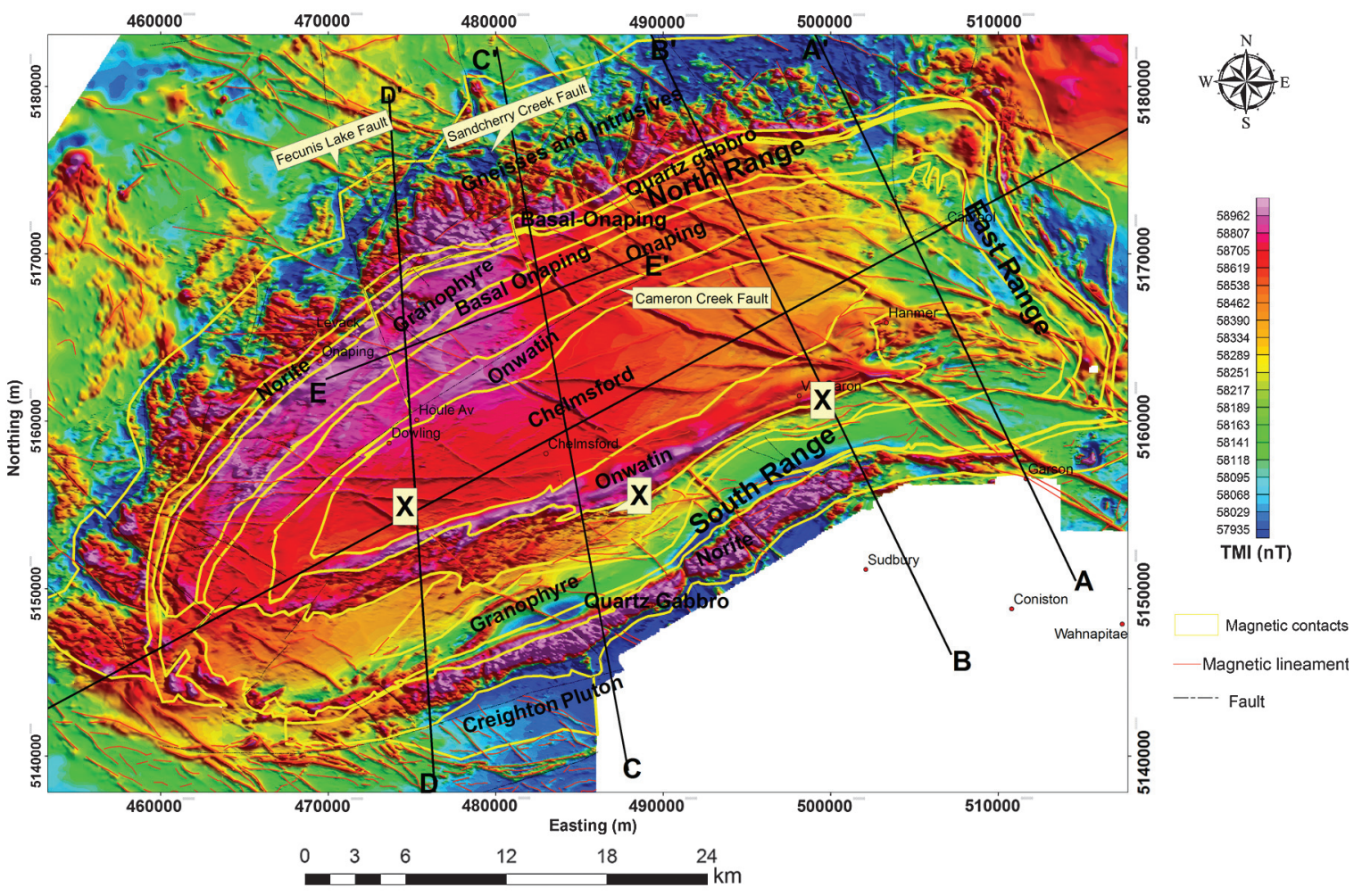

b)



Figure 1. (a) Total magnetic intensity, (b) Bouguer gravity fields of the Sudbury Structure showing the high gravity response delineating the elliptical rim of the SIC. Profile A-A' through E-E' shows the locations of data used to create the $2.5 \mathrm{D}$ gravity and magnetic models. 


\section{Geologic assumptions for the 2.5D geophysical models}

Geologic assumptions for the models rely primarily on the Lithoprobe seismic interpretations (Milkereit and Green, 1992; Olaniyan et al. (2014). We assume that the seismically delineated south-dipping topography of
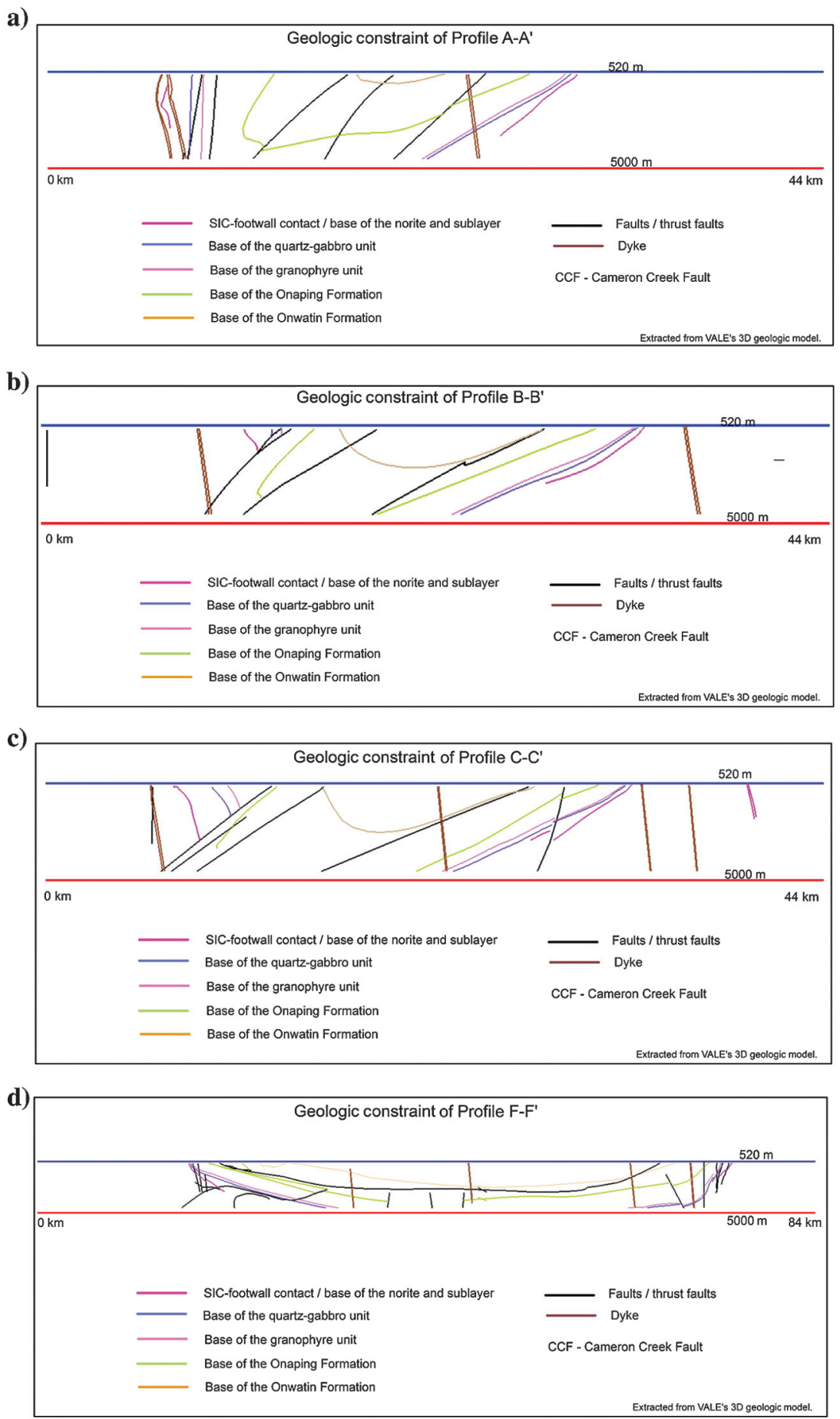

Figure 2. Geologic section of the profile A-A', B-B', C-C', and F-F' extracted from Vale's 3D geologic model. The various colored lines indicate the approximate contacts of the different rock units of the Sudbury Structure based on drilled holes and other geologic data: The black south-dipping lines are faults, and the brown double lines are dykes. the Archean basement rocks from the Lithoprobe section (Milkereit and Green, 1992) is continuous under the SIC, and it is essentially replicated on all sections. Twomensional geologic sections were extracted along the six profiles (Figure 1a and 1b) from Vale's 3D geologic model, which was developed from borehole geologic data (S. Dickie, personal communication, 2013). These 2D geologic sections that define the base of the different rock units of the Sudbury Structure along the selected profiles were used to constrain the top of the SIC between the depths of 520 and $5000 \mathrm{~m}$ (Figure 2a-2d). The geologic sections are well constrained by borehole data up to an approximate 2$3 \mathrm{~km}$ depth, after which geologic contact and structures were projected further down to approximately $5 \mathrm{~km}$ supported by geologic data. Information presented below $2-3 \mathrm{~km}$ in the geologic sections is treated as an interpretative constraint with a lower degree of confidence during the modeling and was not strictly adhered too.

The continuity of the linear gravity high under the Sudbury Basin into the eastern part of the south range (Figure 1b) could imply that the source of the anomaly also extends likewise to the east. To investigate this assertion, the interpreted north-verging fold at the basal part of the SIC in the south range (Olaniyan et al. [2014], Figure 5) is included in all the north-northwest profiles.

The magnetic susceptibility and densities values of the different lithologic unit in the models are the same as presented in Olaniyan et al. (2014). They are from published magnetic susceptibility, natural remanent magnetization, and density values (Table 1) obtained from surface and borehole samples within the Sudbury Structure (Hearst et al., 1994; McGrath and Broome, 1994). Due to the level of alteration and deformation, the distribution of magnetic minerals is not uniform within similar rocks in the Sudbury Structure (Hearst et al., 1994), so the susceptibility values were allowed to vary from the estimated values by approximately \pm 0.005 SI. The direction of the natural remanence was kept constant, and the magnitude was also allowed to vary (Hearst et al., 1994). Similarly, the density values of some rocks were varied up to $\pm 0.02 \mathrm{~g} / \mathrm{cm}^{3}$ to achieve a good fit.

The magnetic field strength data reflect the spatial distribution of magnetic 
minerals: typically magnetite and/or pyrrhotite in the source rock. This magnetic field strength can be interpreted to estimate the contact locations, depth, and orientation of the source body. However, alteration, mineralization, and deformational events tend to either create or destroy magnetic minerals in the rock, introducing complexities into the interpretation process. This can be a disadvantage, but it can also be used to map alteration zones. The gravity field on the other hand is indicative of the distribution of the density distribution of rocks. Simultaneous interpretation of magnetic and gravity data along the selected profiles in GMSYS aids in interpretations of the geometric configuration of lithologic units, faults orientations, dykes, and shear zones of the Sudbury Structure. The 2.5D sections that formed the basis for the modeling are discussed below.

\section{D geologic mapping}

When there is limited subsurface geologic data such as borehole logs and seismic data, a representation of the subsurface geometry can be approximated from potential field data, which is a function of the 3D distribution of the source (Lane and Guillen, 2005). Magnetic and gravity sources are interpreted along the $2.5 \mathrm{D} \mathrm{sec}-$ tions, and then, the latter are interpolated and extrapo- lated to construct an initial 3D geologic model that is broadly representative of the subsurface geometry. This 3D geologic model, generated directly from observed field measurements, can be revised as more geologic data become available and are quickly recomputed in 3D GeoModeller.

A volume covering the minimum and maximum longitude and latitude of the study area was defined to a depth of 15 and $1 \mathrm{~km}$ above the topographical surface. The six interpreted 2.5D sections were imported into GeoModeller in an image file format (.png) because of the lack of good data exchange format between GM-SYS and 3D GeoModeller. One of the difficulties of using an image file format is that an average topographic surface has to be assumed for each section, which introduces elevation issues into the $3 \mathrm{D}$ forward modeling and inversion processes.

Contacts and orientation data of the geologic units in the surface geologic map and the interpreted 2.5D sections are digitized and attributed in 3D GeoModeller. This geologic modeling package is developed based on potential field theory (McInerney et al., 2005), and it defines known contacts of a geologic unit as an isopotential surface, whereas the orientation data determine the gradient and direction of the isosurfaces. Using a cokriging interpolation technique (McInerney

Table 1. Physical properties of rocks used to compute the calculated field in the models. Density contrast values are from McGrath and Broome (1994). Magnetic susceptibility and natural remanence values (magnetic inclination, declination, and intensity) are modified from Hearst et al. (1994). The magnetic susceptibility values were allowed to deviate by -0.005 SI from the actual, and the density contrast in varied up to $-0.05 \mathrm{~g} / \mathrm{cm}^{3}$ at some instances.

\begin{tabular}{lccccc} 
Rock unit & Magnetic susceptibility (SI) & NRM & Density $\left(\mathrm{kg} / \mathrm{m}^{3}\right)$ \\
\hline SIC north range & & Declination $\left(^{\circ}\right)$ & Inclination $\left(^{\circ}\right)$ & Intensity (SI) & Varied \\
Norite & 0.035 & 316 & 69 & Varied & 2810 \\
Quartz gabbro & 0.035 & 329 & 68 & Varied & 2700 \\
Granophyre & 0.025 & 329 & 68 & & \\
SIC south range & & & & Varied & 2810 \\
Norite & 0.004 & 189 & 64 & Varied & 2880 \\
Quartz gabbro & 0.035 & 189 & 64 & Varied & 2700 \\
Granophyre & 0.001 & 116 & 84 & & Varied \\
Whitewater group & & & & Varied & 2770 \\
Onaping & 0.025 & 130 & 21 & Varied & 2750 \\
Onwatin & 0.010 & 291 & 75 & & 2880 \\
Chelmsford & 0.010 & 291 & 75 & & 2730 \\
Dense Levack gneiss & 0.068 & & - & & 2650 \\
Levack gneiss & 0.047 & & & & 2850 \\
Cartier granite & 0.012 & & & & 2700 \\
Dykes & 0.024 & & & & 2880 \\
Huronian sediment & 0.014 & & & & 2760 \\
Huronian mafic & 0.029 & & & & \\
Creighton & 0.025 & & & & \\
\hline
\end{tabular}


et al., 2005) and obeying the defined chronostratigraphic order of the geologic sequence, defined contacts and orientation data in the geologic map and the 2.5D lithofence are interpolated to generate coherent 3D geologic curvilinear surfaces, which approximate the defined contacts of the rock units (Lajaunie et al., 1997).

\section{D geophysical modeling}

The 3D geologic model of the Sudbury Structure is forward modeled to compute the predicted geophysical response on a grid. This is compared to the measured data to iteratively estimate the misfit and modify the $3 \mathrm{D}$ geologic model. The forward-modeling algorithm assumes petrophysical attributes for each geologic unit and uses the same parameters to characterize the ambient earth's magnetic field. Computation of the gravity response used published densities values (Table 1, Gupta et al., 1994; McGrath and Broome, 1994; Hearst and Morris, 2001). The average density value of the LGC $\left(2.73 \mathrm{~g} / \mathrm{cm}^{3}\right)$ background was assumed to be the reference background density value.

The forward-modeling algorithm in GeoModeller requires that an observation point be defined at a given height above the topography. The 3D volume is converted into geologic voxels the size of which is selected by the user. The attributes at the center of each voxel are assumed to be representative of the entire cell size.
Therefore, the smaller the cell size, the better the apparent resolution, but more computing power and time are required. GeoModeller allows for the vertical height of the cells to be variable, so the cell resolution close to surface to a specified depth can be made finer to fit the topography better than the deeper cells, which are larger.

Our derived 3D geologic model is converted into $1000 \mathrm{~m} \times 1000 \mathrm{~m}$ voxel sizes in the $x$ - and $y$-directions. In the $z$-direction, the cell size is $1 \mathrm{~m}$ from the surface topography to a $-200 \mathrm{~m}$ depth, whereas the cell size from $-200 \mathrm{~m}$ to $-15 \mathrm{~km}$ is at $1000 \mathrm{~m}$. The predicted gravity and magnetic response are computed at $1 \mathrm{~m}$ above the surface.

\section{Results and discussions 2.5D geologic models}

The 2.5D sections across the SIC all have an Archean basement dipping gently $\left(\sim 30^{\circ}\right)$ to the south (Milkereit and Green, 1992). The Archean basement rocks are in steep, north-dipping contact with the Cartier Batholith, and they are overlain by Huronian supracrustal rocks to the south (Figure 3). The northwest-trending olivine diabase dykes were emplaced along faults cutting across the Sudbury Structure, and they regionally contribute to the observed magnetic and gravity fields in the region. Figures 3-6 show the interpreted geometry of the SIC along four interpreted sections A-A', B-B', C-C',

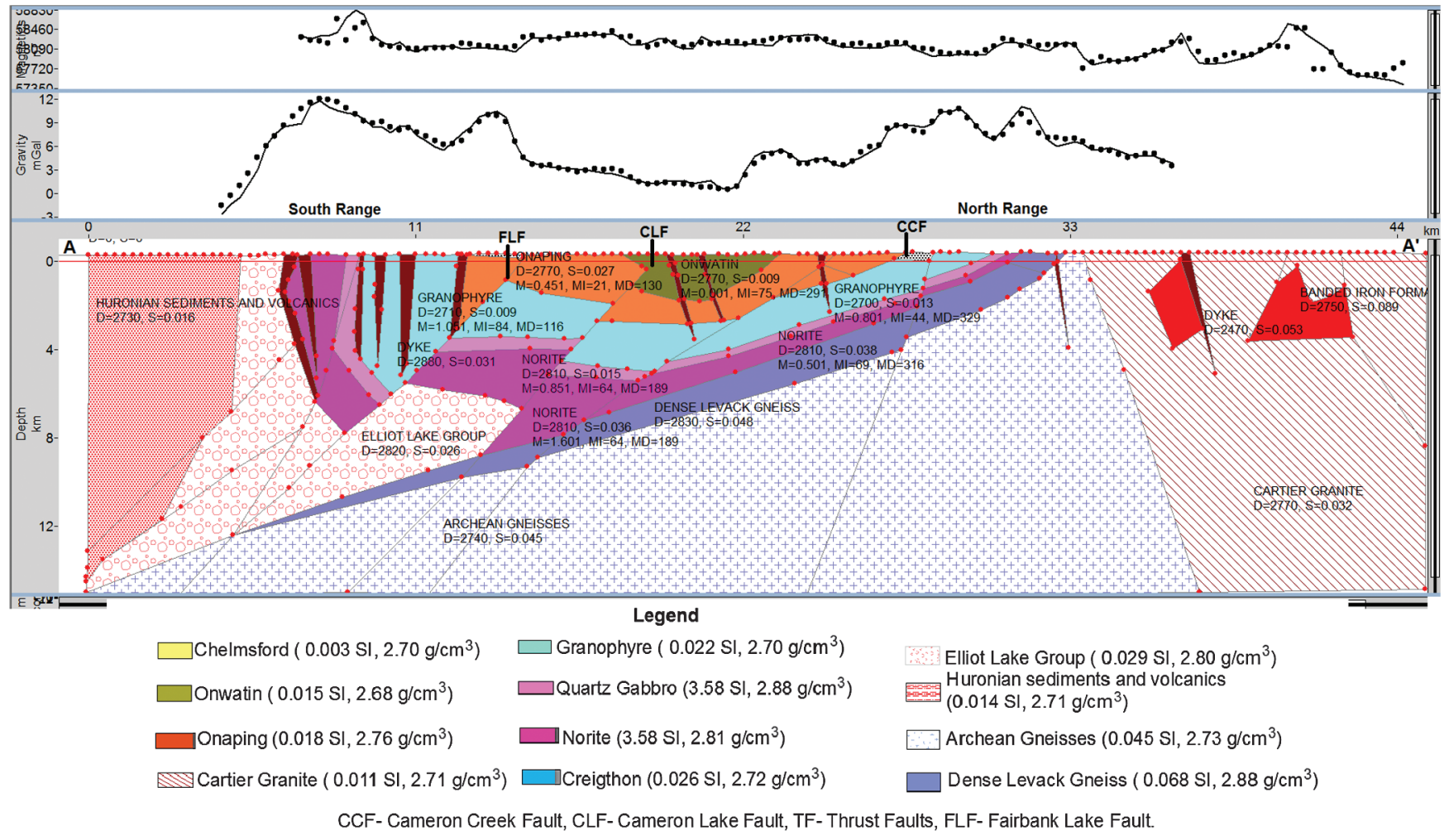

Figure 3. The 2.5D geologic model for profile $\mathrm{A}-\mathrm{A}^{\prime}$ (bottom) and the corresponding magnetic (top) from the compilation of Olaniyan et al. (2013) and airborne gravity data (middle) provided by Vale. The measured data are the thick dotted line, and the forward model data are the thin solid line. 
and F-F' below. Profiles D-D' and E-E' have been previously described (Olaniyan et al., 2014). The north-northwest profiles are all viewed facing west (south range to the north range), whereas the longitudinal profile is viewed facing north (west is on the left and east is on the right).

\section{Profile $A-A^{\prime}$}

The most easterly profile A- $\mathrm{A}^{\prime}$ is $44 \mathrm{~km}$ in length and parallel to the east range (Figure $3 \mathrm{a}$ ) where the magnetic and gravity fields are generally low. This low magnetic field zone was interpreted along the longitudinal section (see F-F' below) and shows that a series of east-dipping, north-south faults parallel to the east range has downthrown the basement and the SIC rock. On profile A-A', moving from left to right, there is no airborne geophysical data coverage over the Huronian sedimentary rocks; the high magnetic and gravity response at approximately $8 \mathrm{~km}$ along the profile corresponds to the Elliot Lake mafic volcanic rocks, south range norite, and quartz gabbro, whereas granophyre exhibits relatively lower magnetic and gravity responses (Figure 3a). The rocks of the SIC and Huronian strata in this part have been overturned, and they are almost vertical or steeply dipping to the south (Card, 1965). In the south range, a local grav- ity high due to the Onaping Formation at approximately $13 \mathrm{~km}$ on the profile sits on a much broader and more subtle magnetic and gravity high, which terminates abruptly around $18 \mathrm{~km}$ by the Cameron Lake Fault (CLF) along the profile. This subtle gravity high appears to have originated from a deeper source and is interpreted to be a product of thrusting of the SIC and the Elliot Lake mafic volcanic rocks along the Fairbank Lake Fault (FLF) and the CLF to an approximate 4-6 km depth.

At $30 \mathrm{~km}$, a normal fault displaces the SIC in the north range down to the south resulting into a discontinuity and low magnetic and gravity fields. The high gravity and fairly high magnetic field observed in the north range to the north of this fault is due to dense Levack gneisses, norite, and quartz gabbro. The contact between the gently south-dipping LGC and the Cartier Batholith dips to the north (Milkereit and Green, 1992) and exhibits a sharp discontinuity in the magnetic and gravity fields. Banded iron formations further north near the boundary of the Cartier Batholith and Huronian supracrustal rocks exhibit relatively high magnetic signature (Figure 1a).

\section{Profile $B-B^{\prime}$}

Profile B-B' (Figure 4) is $44 \mathrm{~km}$ long and is located $8.5 \mathrm{~km}$ west of profile A-A'. The magnetic field across

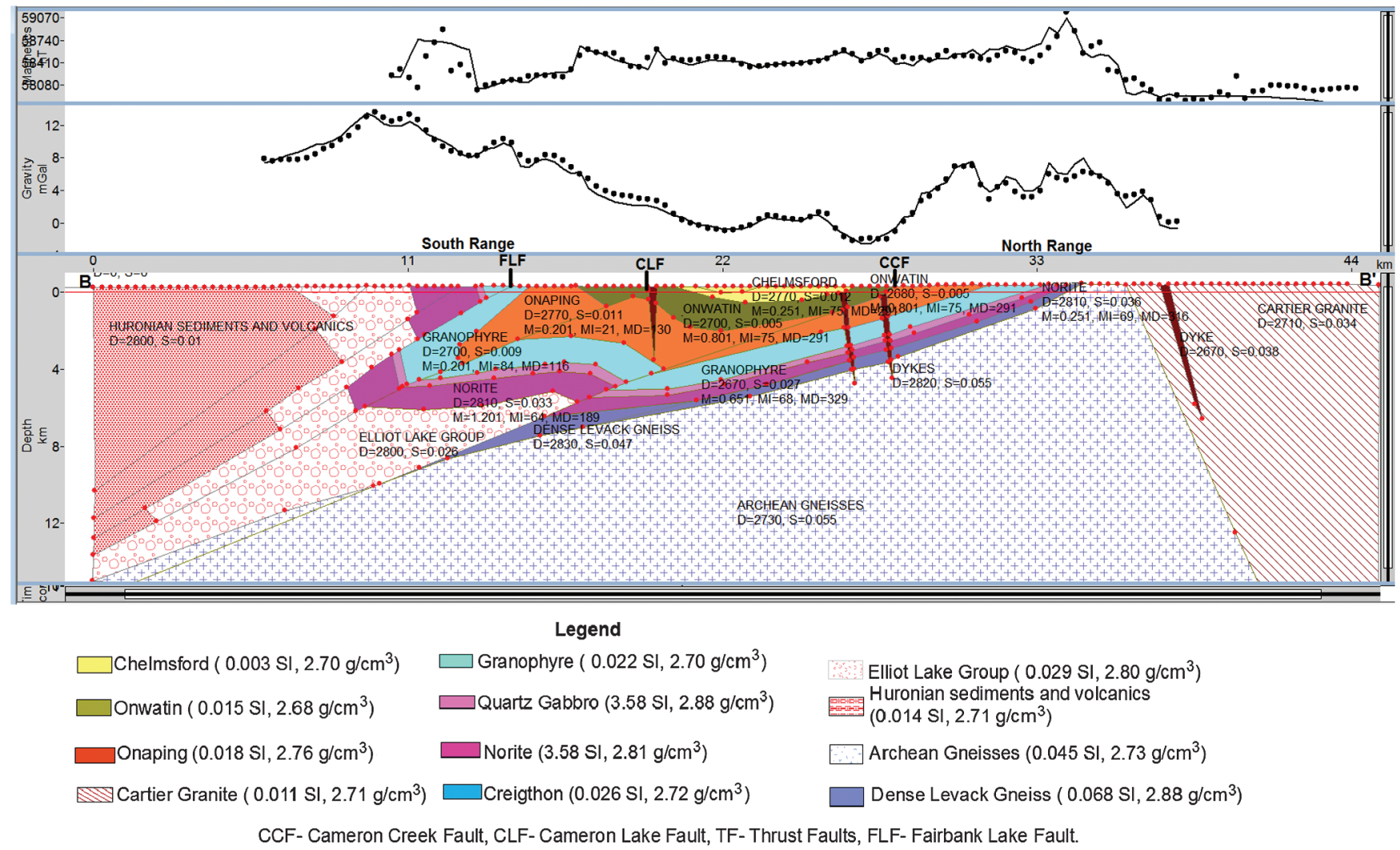

Figure 4. The 2.5D geologic model for profile B-B' (bottom) and the corresponding magnetic (top) from the compilation of Olaniyan et al. (2013) and airborne gravity data (middle) provided by Vale. The measured data are the thick dotted line, and the forward model data are the thin solid line. Note the difference in the gravity response over the Onwatin Formation in the south range and north range. 

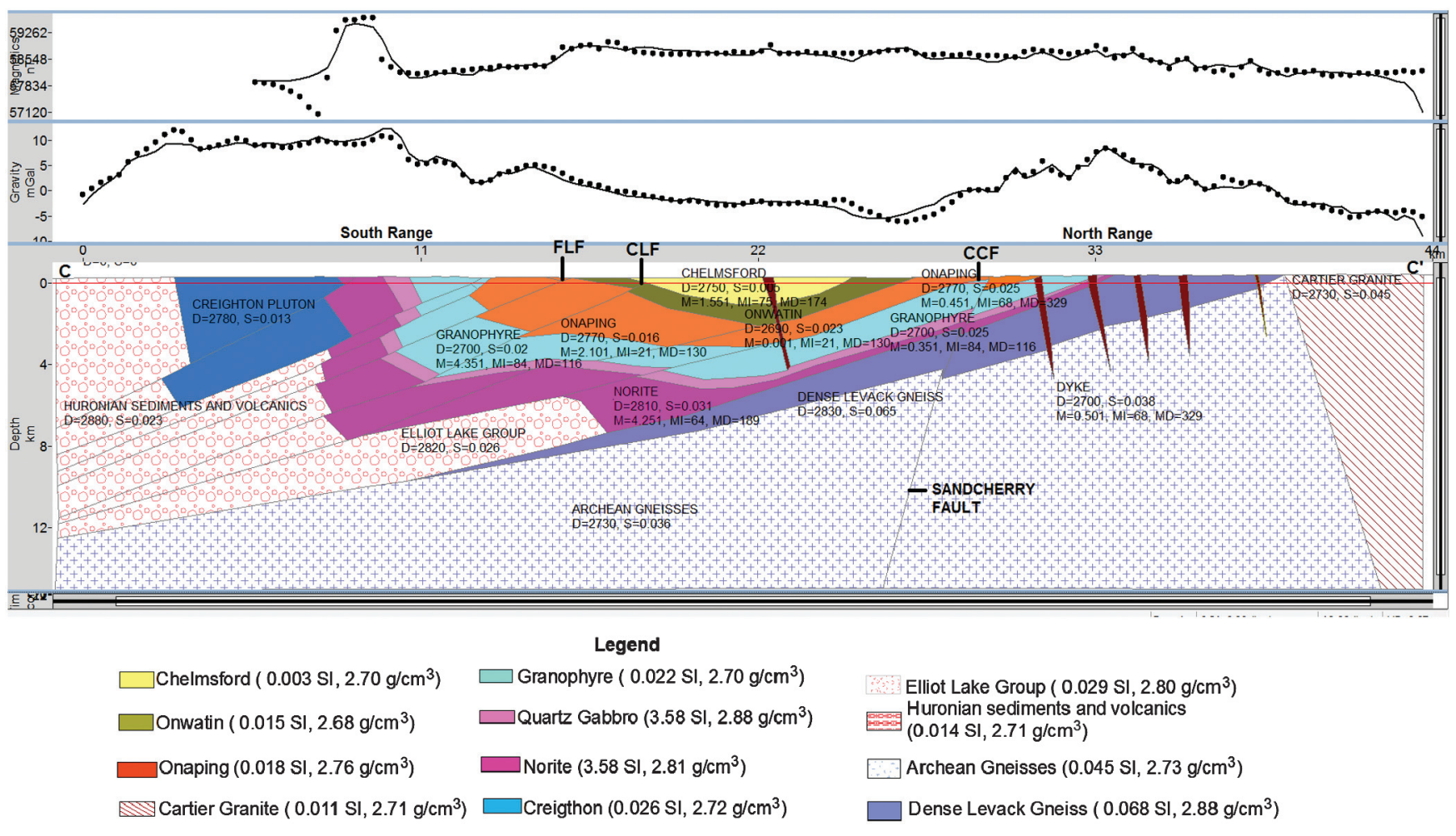

CCF- Cameron Creek Fault, CLF- Cameron Lake Fault, TF- Thrust Faults, FLF- Fairbank Lake Fault.

Figure 5. The 2.5D geologic model for profile C-C' (bottom) and the corresponding magnetic (top) from the compilation of Olaniyan et al. (2013) and airborne gravity data (middle) provided by Vale. The measured data are the thick dotted line, and the forward model data are the thin solid line. The measured data in the thick dotted line broadly fit the calculated field in the thin solid line.

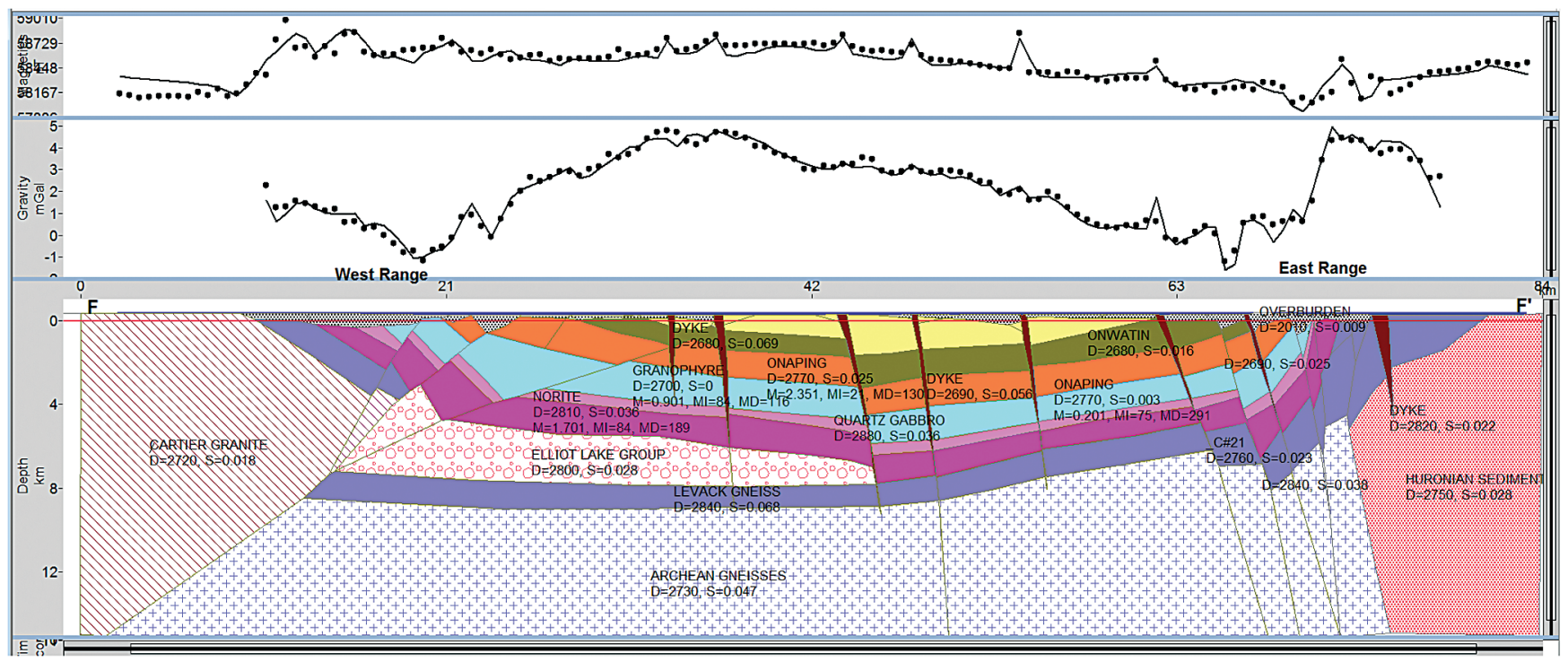

Legend

\begin{tabular}{|c|c|}
\hline$\square$ Chelmsford ( $0.003 \mathrm{SI}, 2.70 \mathrm{~g} / \mathrm{cm}^{3}$ ) & $\square$ Granophyre ( $0.022 \mathrm{SI}, 2.70 \mathrm{~g} / \mathrm{cm}^{3}$ ) \\
\hline Onwatin $(0.015 \mathrm{SI}, 2.68 \mathrm{~g} / \mathrm{c}$ & Gabbro $\left(3.58 \mathrm{Sl}, 2.88 \mathrm{~g} / \mathrm{cm}^{3}\right)$ \\
\hline $\mathrm{O}$ & Norite $\left(3.58 \mathrm{SI}, 2.81 \mathrm{~g} / \mathrm{cm}^{3}\right)$ \\
\hline Cartier Granite ( $0.011 \mathrm{SI}, 2.71 \mathrm{~g} / \mathrm{cm}^{3}$ ) & Creigthon $\left(0.026 \mathrm{SI}, 2.72 \mathrm{~g} / \mathrm{cm}^{3}\right)$ \\
\hline
\end{tabular}

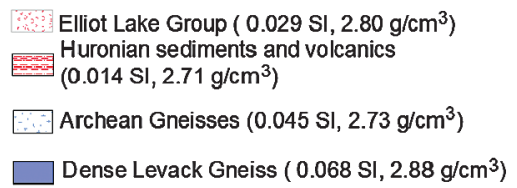

CCF- Cameron Creek Fault, CLF- Cameron Lake Fault, TF- Thrust Faults, FLF- Fairbank Lake Fault.

Figure 6. The 2.5D geologic interpretation along the longitudinal section F-F' (bottom) and the corresponding magnetic (top) and gravity (middle) data from the compilation of Olaniyan et al. (2013) and the airborne gravity data provided by Vale. The measured data in thick dotted line broadly form a dome shape and have higher intensities in the western part of the SIC. The calculated field is the thin solid line. 
this profile is relatively stronger than on profile A- $\mathrm{A}^{\prime}$ and ranges from 57,910 to $59,152 \mathrm{nT}$ with the highest magnetic and gravity peaks over the SIC and dense LGC rocks and lowest over the Whitewater sedimentary series. At approximately $10 \mathrm{~km}$ in the south range, a broad double-peak gravity anomaly is observed, this is interpreted to be part of the thrust rocks of the SIC and the Elsie Mountain Formation that were later overturned at an approximate $3-6 \mathrm{~km}$ depth. The local gravity anomaly over the Onaping at $16 \mathrm{~km}$ and broader subtle gravity high ascribed to the proposed SIC basal deformation on $\mathrm{A}-\mathrm{A}^{\prime}$ is also evident $\mathrm{B}^{-\mathrm{B}^{\prime}}$ and gradually reduces until approximately $22 \mathrm{~km}$ along the profile. On profile $\mathrm{B}^{-\mathrm{B}^{\prime}}$, the basal deformation is controlled by the Cameron Creek Fault in the north and Cameron Creek Fault in the south. The Onwatin Formation $\left(2.68 \mathrm{~g} / \mathrm{cm}^{3}\right)$ exhibits a relatively low gravity field in the north range in comparison with the south range, which also signifies the presence of a denser and probably deeper source of the gravity anomaly in the south range. The northdipping contact of the Archean basement rocks and the Cartier granite shows a very steep magnetic gradient.

\section{Profile $C-C^{\prime}$}

Profile C-C' (Figure 5) is located $14 \mathrm{~km}$ west of profile BB. It is $44 \mathrm{~km}$ in length and from the south to north transects the Huronian supracrustal rocks, Creighton pluton, SIC, LGC, and Cartier Batholith. The Huronian rocks and the Creighton pluton exhibit low magnetic intensity south of the high magnetic field caused by the norite and quartz gabbro. Although the magnetic field is relatively smooth, the gravity data show variation in the distribution of the subsurface masses.

A fairly high gravity anomaly of approximately 10 mgal between 3 and $10 \mathrm{~km}$ along the section corresponds to the south range SIC, Creighton pluton, and basal Huronian mafic intrusions that occur at the footwall. The extensive high gravity observed over the Creighton Pluton can be explained by the presence of dense mafic volcanic rocks of the Elliot Lake Group. A relatively low gravity field is observed over the granophyre, whereas the local gravity high due to the Onaping Formation continues from previous parallel profiles. The subtle broader gravity anomaly, which gradually fades northward, corresponds to the location of the change in dip of the north range as observed in the Lithoprobe seismic section (Milkereit and Green, 1992). The northern extension of the Onwatin Formation $\left(0.68 \mathrm{~g} / \mathrm{cm}^{3}\right)$ exhibits a very low gravity field. The high gravity field in the north range is related to the noritegabbro rocks, Levack gneiss, as well as mafic dykes $\left(2.70 \mathrm{~g} / \mathrm{cm}^{3}\right)$ in that portion.

\section{Profile F-F}

Profile $\mathrm{F}-\mathrm{F}^{\prime}$ is $84 \mathrm{~km}$ long and traverses the longitudinal axis of the SIC (Figure 6). Regionally, the measured magnetic and the gravity responses are shaped like a dome, with a low response at either end, whereas the central part of the profile has a relatively high re- sponse. However, there is a pronounced gravity high associated with dense Levack gneiss at the west and east ends of the traverse. At this scale, the focus was to model the regional mass distribution of rocks at the subsurface and major structures such faults and dykes infilling fault zones causing the dome shape of the measured fields, with less attention to minor lineaments along the longitudinal section. On the western flank, normal faults have displaced the southwestern portion of the SIC downward. These faults are interpreted to be post-SIC and near-surface; they do not affect the Archean basement (Figure 2d), but likely resulted into a relative low gravity field from 10 to approximately $23 \mathrm{~km}$ along the profile due to the downthrow of the SIC rocks and presence of approximately $100 \mathrm{~m}$ of overburden. Vermilion Lake, FLF, and Gordon Lake occur around this region, and these could have occupied the depression created by the displacement. The proposed basal deformation of the SIC by the Huronian mafic rocks occurs along the profile up to approximately $43 \mathrm{~km}$, and then it verges southward away from the profile. This part of the SIC is uplifted relative to the eastern flank and is controlled by a fault zone infilled by a dike. It is not clear at this point, if this infilled fault is related to the growth faults interpreted in the north range along the $\mathrm{E}-\mathrm{E}^{\prime}$ profile discussed by Olaniyan et al. (2014). This uplifted western part of the SIC might have also contributed to the high magnetic field observed in the western half of the SIC (Figure 1a). The low magnetic and gravity fields parallel to the east range at approximately $63 \mathrm{~km}$ are explained by a series of closely packed north-south-trending east-dipping normal fault systems (Figure 6).

\section{Airborne magnetic and anomaly maps}

In the gridded data (Figure 1a), the low magnetic field zone extends from the north range footwall to the south range, suggesting the preexistence of a north-norhwest-fault/shear system in the Archean basement before the emplacement of the SIC. This basement fault must have been reactivated to deform the SIC. Rocks of the SIC, LGC, and the Archean gneisses have been downthrown to the east, allowing for approximately 100-150-m-thick overburden cover near the east range. This linear fault zone contains Joe Lake in the north range and the Joe Lake mafic intrusion in the footwall. Joe Lake is elongated in shape and aligned with this north-northwest-fault zone, so it might also be structurally controlled. Ames et al. (2013) describe the Joe Lake mafic intrusion fabric as penetrative and preliminary U-Pb geochronology of Joe Lake mafic intrusion also indicates that it was metamorphosed in the Archean (2657 $\pm 9 \mathrm{Ma}$; Ames et al., 2013). This indicates that the Joe Lake mafic intrusion might have been localized along the north-northwest fault zone during the Archean - An interpretation that is consistent with the presence of the fault preemplacement of the SIC. Considering the geologic setting and the occurrence of sulfides in the base of Joe Lake (Watts, 1997), the north-northwest-fault zone might 
have controlled sulfide mineralizations associated with the SIC, and therefore are likely prospective.

\section{D geologically constrained model}

The imported 2.5D geologic images were modified and aligned to ensure continuities among lithologic units and structures in the 3D GeoModeller software Figure $7 \mathrm{a}$ and $7 \mathrm{~b}$. This lithofence diagram of the inter- preted geologic features in combination with the surface geology map forms the inner framework of the 3D geologic volume, from which the geology of unknown areas was inferred by extrapolation (Figure 8).

The generated 3D geologic model provides insights into some of the unexplained regional geophysical anomalies within the SIC. Visual inspection of the SIC from any perspective in space is possible in this

a)

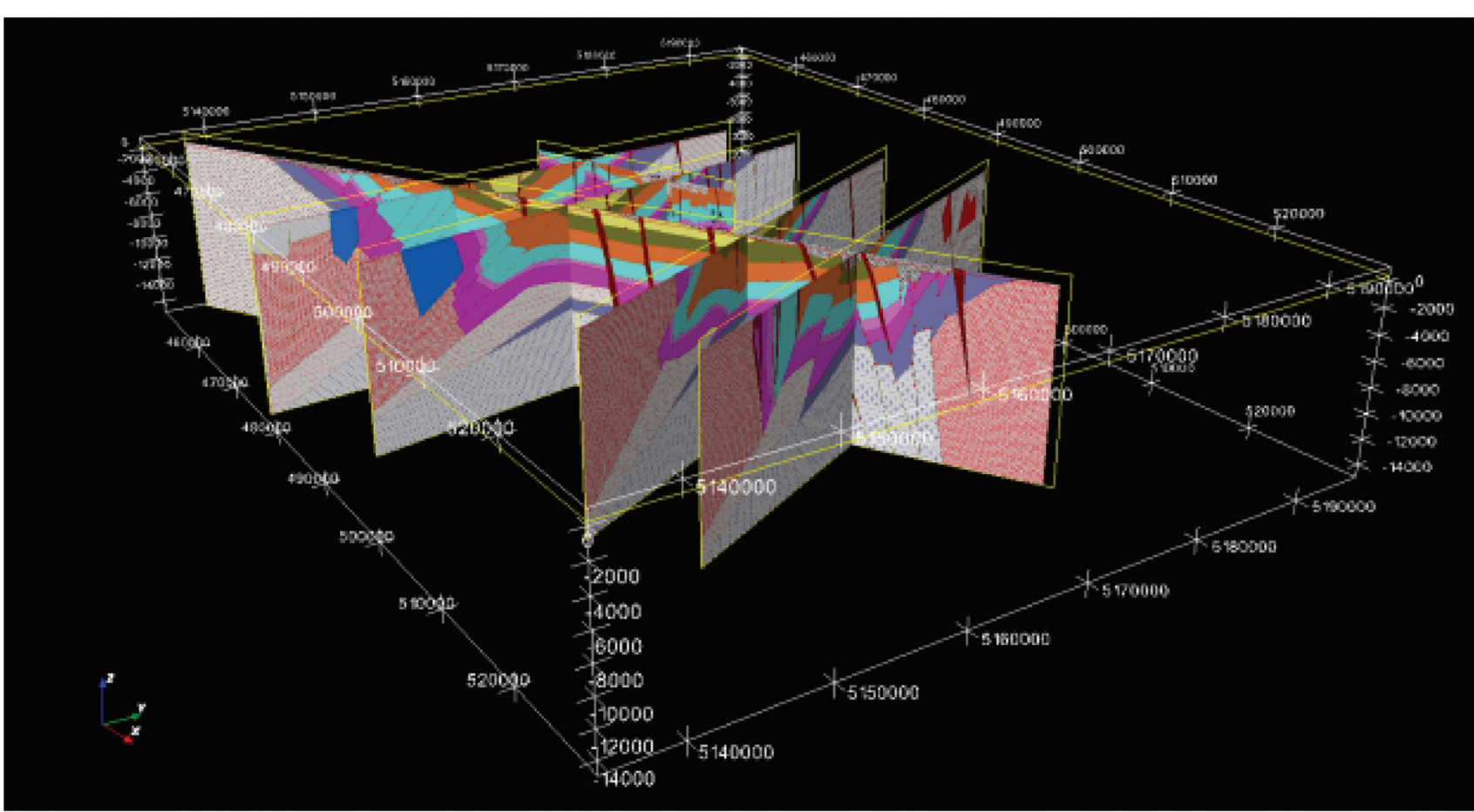

b)

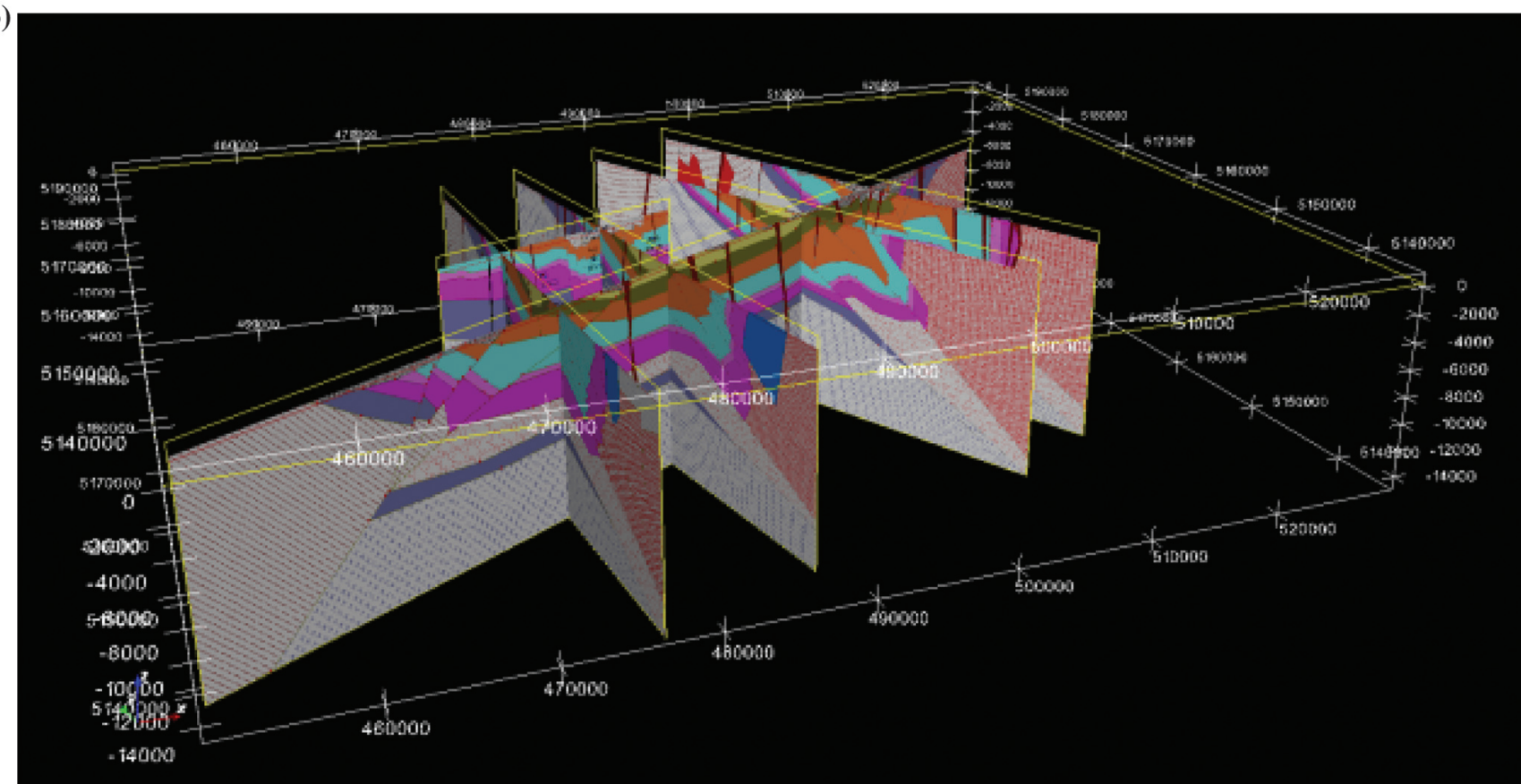

Figure 7. Different perspectives of the lithofence diagram that forms the framework of the 3D geologic volume: (a) facing northwest and (b) facing northeast. 
3D mode, making it easier to evaluate the proposed hypothesis and past interpretations related to the deformation and geologic setting of the SIC. At this regional scale, the resolution of the derived 3D volume does not accommodate most of the known and interpreted fault displacements and some of the downthrown blocks evident in the $2.5 \mathrm{D}$ sections. A limitation of the modeling process is that unconsolidated sediments that have accumulated in the depressions created by the normal faults are difficult to model because it was necessary to specify constant topography for each $2.5 \mathrm{D}$ image in GeoModeller.

Regionally, the 3D geologic model illustrates that the increased thickness of the LGC in the western half appears to explain the higher magnetic and gravity fields observed in this part of the sudbury structure (SS) (Olaniyan et al., 2014). There appears to have been some relative movement of basement rocks in the central portion of the SIC marked by a series of growth faults as expressed by gradual changes in the potential field data (Olaniyan et al., 2014) around the Sandcherry Fault in the north range. Growth faults appear to have downthrown the basement and the SIC rocks resulting in a low gravity field around the Sandcherry fault. However, geophysical signatures of the growth fault system do not occur on the more southern longitudinal profile F-F ${ }^{\prime}$, which suggests that the faults were active in the north range of the SIC and likely originate from a location around the Sandcherry Fault. A series of converging faults mapped at surface around the Sandcherry Fault may be related to this system (Ames et al., 2005). Depending on the timing of these faults, they could have acted as conduits for hydrothermal/mineralized fluids within the Sudbury Basin and perhaps the SIC (Ames and Farrow, 2007). As projected from the subsurface, the thicknesses of the SIC rocks vary between geographic areas. There is more volume of SIC rocks at depth in the south range compared to the north range, likely because the south range has undergone greater tectonic shortening (Shanks and Schwerdtner, 1991).

\section{D forward modeling}

Computation of the gravity field for the 3D geologic model allows for evaluation of the applicability of the geologic interpretations presented and provides additional constraints on the geologic setting to reduce the misfit between the measured and predicted fields. The high resolution measured Bouguer gravity response along the selected profiles was also compared to the computed field. Although this approach is able to highlight area of misfit along the profiles, it does not provide the regional synoptic view required to assess the continuity of geologic features away from the profiles. For example, Figure 9 shows the broad

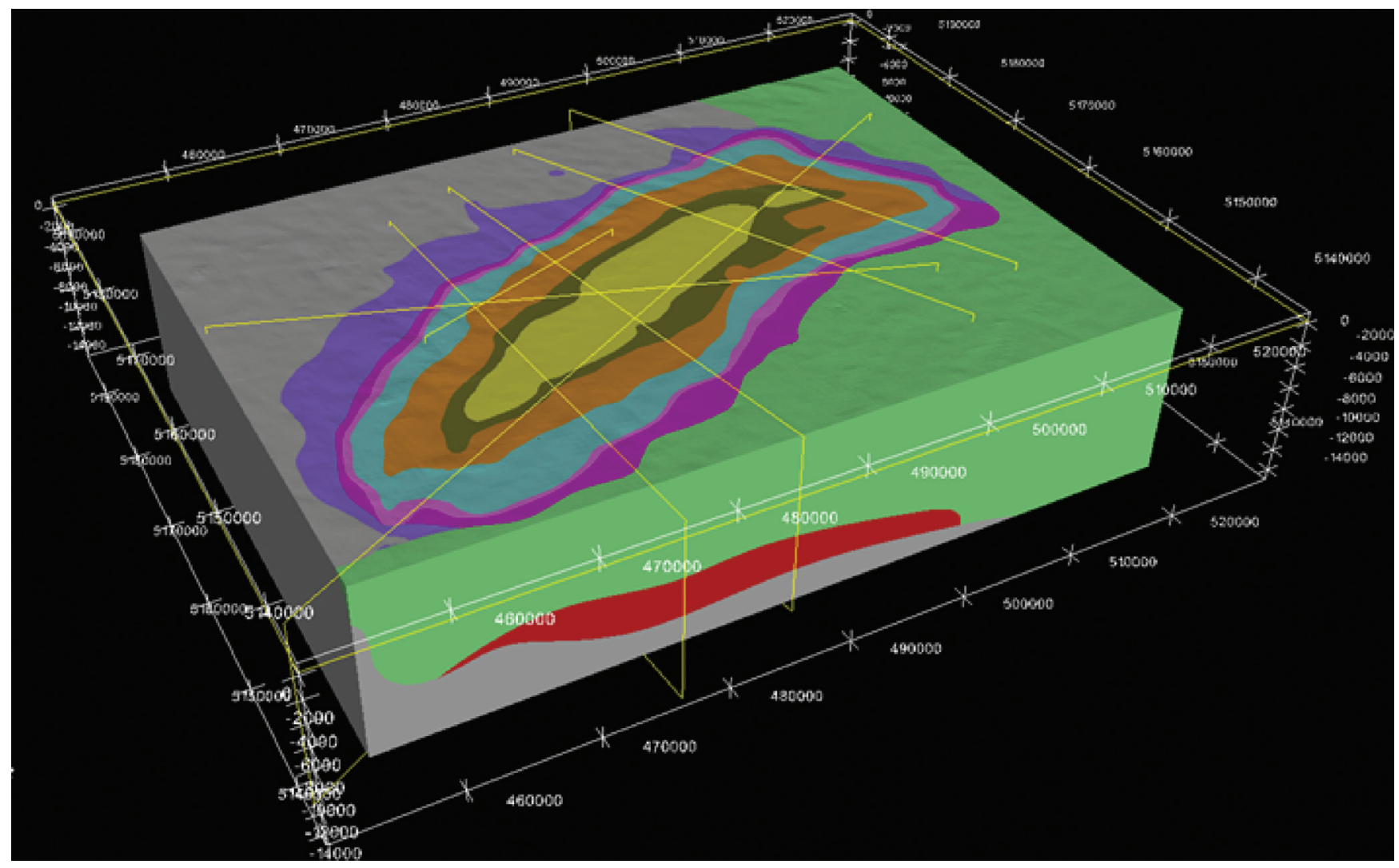

Figure 8. Derived 3D geologically constrain model of the Sudbury Structure that is consistent with the surface geologic map, orientation data, and subsurface geometry along the interpreted $2.5 \mathrm{D}$ geologic sections. 
correlation of the measured and computed gravity response along profile $\mathrm{B}^{-} \mathrm{B}^{\prime}$, but it also highlights areas of misfits.

The computed gravity map (Figure 10) was quantitatively assessed by comparing it to the available low-resolution, free-air gravity data of the Geological Survey of Canada database (Figure 11). Vale's proprietary highresolution gravity grid was not used because of confidentiality restrictions. The geometry of the initial 3D geologic model and density values were iteratively ad- justed and recomputed, until a predicted field broadly similar to the measured gravity field was attained.

High-gravity field intensity delineates the elliptical rim of the Sudbury Structure in the south range and east range in the measured and the calculated gravity response. This broad response is attributed to the norite $\left(2.81 \mathrm{~g} / \mathrm{cm}^{3}\right)$, quartz gabbro $\left(2.88 \mathrm{~g} / \mathrm{cm}^{3}\right)$, and basal Huronian tholeiitic basalt of the Elliot Lake Group $\left(2.80 \mathrm{~g} / \mathrm{cm}^{3}\right)$, and other mafic intrusions such as the Nipissing diabase and trap dykes, which were not

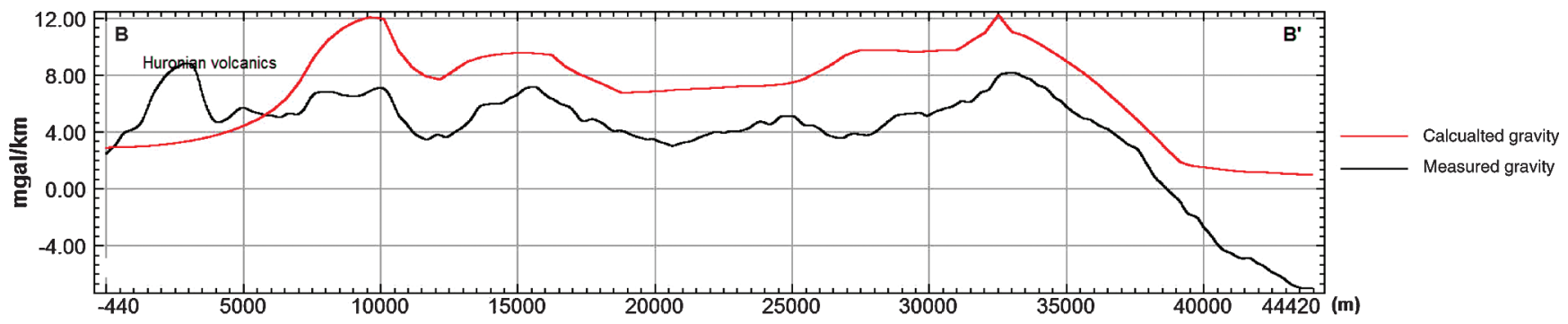

Figure 9. Plot of the measured Bouguer versus the calculated gravity response of the 3D geologic model along profile B-B'. The calculated response is consistent with the measured gravity field but exhibits higher intensity. The measured field was Bouguer corrected using $2.91 \mathrm{~g} / \mathrm{cm}^{3}$, which is much higher than the reference background density of $2.73 \mathrm{~g} / \mathrm{cm}^{3}$. High gravity observed before $5000 \mathrm{~m}$ is due to mafic volcanics, which were not included in the model.

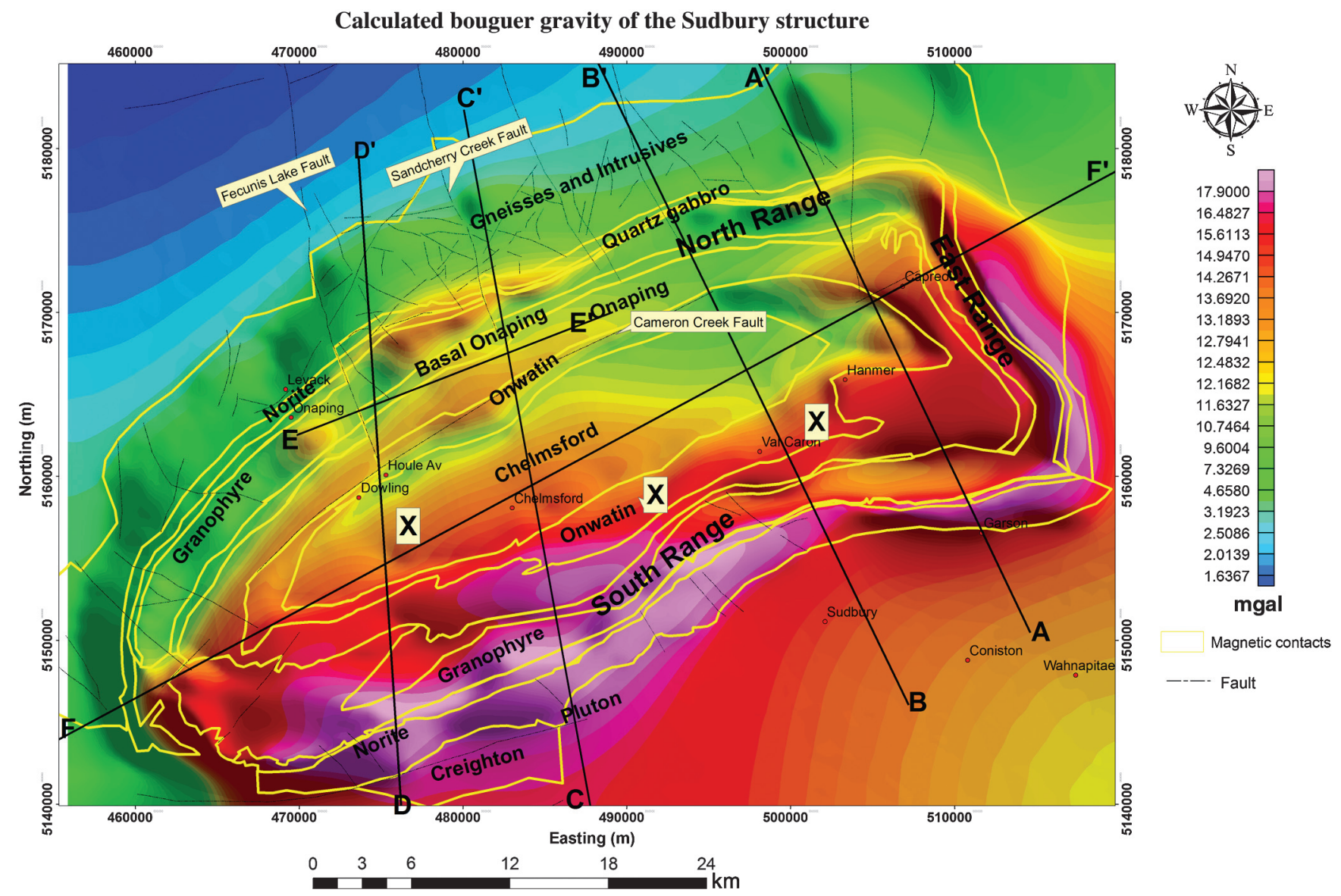

Figure 10. Computed gravity response of the $3 \mathrm{D}$ geologic model spatially computed at a $1 \mathrm{~m}$ distance above the surface. 
included in our geologic model. The basal mafic volcanic rocks at the base of the Huronian sequence appear to have been thrust northward to under the Sudbury basin, where it is wedged beneath the SIC resulting in a north-verging fold and deformation of the basal part of the SIC in the south range. The presence of this highly dense mafic rock $\left(2.80 \mathrm{~g} / \mathrm{cm}^{3}\right)$ and the relative shallowness of the SIC rocks at the southern border of the Sudbury Basin are able to generate the linear gravity high (marked with $\mathrm{X}$ in Figure 10).

The western part of the north range contains dense LGC up to $4 \mathrm{~km}$ in thickness, which results in a high gravity response seen in the calculated and the observed sections or profiles. A low gravity zone dominates the eastern portion of the north range at the junction with the east range. This zone is faulted (see profile $\mathrm{F}-\mathrm{F}^{\prime}$ ) and hosts the Joe Lake mafic intrusion in the footwall contact. As expected, the north range portion of the Whitewater group exhibits a relatively low gravity field even though it dips more gently (average $30^{\circ}$ ) than in the south range (average $55^{\circ}$ ). The gravity low in the northwest portion of the map is due to the Archean basement $\left(2.73 \mathrm{~g} / \mathrm{cm}^{3}\right)$.

\section{Areas of misfit}

The junction of the east range and the north range has been highly faulted and downthrown (see F-F'). This resulted in the low gravity field observed in this region. This structural deformation was difficult to incorporate in this model because the reference surface was the top of each unit, and a constant elevation was specified for each geologic section. Therefore, the youngest unit that can be delineated in the model is the Onwatin Formation, whereas the Chelmsford Formation occupies all spaces above it. This misfit due to the assumed constant elevation used to calculate the gravity response also introduced a discontinuity (low gravity) in the linear gravity anomaly marked X (Figure 10). The gravity high in the southeast of the map is caused by the dense gabbro that forms the Grenville Front, and the gravity low east of the SIC is due to the impact-induced fracturing of rocks of the younger Wanapitei impact crater (Pilkington and Greive, 1992).

Hydrothermal alteration and metamorphism have differentially altered the primary magnetic mineralogy of the SIC, which has resulted in the magnetic properties varying within the same rock type in different parts of the SIC, especially in the south range and east range, where natural remanence magnetization (NRM) is dominant. In order to assign the magnetic susceptibility and NRM values, an "unconformity" was introduced between the north range and the south range at depth, whereas the magnetic properties of the north range and the east range were assumed to be the same. Attempts to forward model the magnetic data did not yield meaningful results.

\section{Discussion on the basal deformation}

In timing the deformational events associated with the Sudbury Structure using the Lithoprobe seismic sec- tion, Wu et al. (1995) identify prominent north-dipping reflections under the Sudbury Basin related to the change in dip of the north range at depth, but they do not provide a geologic interpretation for these features, although they speculate that the features could be due to backfaulting or fracturing. Olaniyan et al. (2014) reinterpret these north-dipping reflectors as being caused either by basement thick-skinned deformation or by the formation of a north-verging fold due to the wedging of basal Huronian volcanic rocks at the SICbasement contact. Geochemical and geologic field evidence that explain the deformation history and patterns of the SIC have been previously described (Shanks and Schwerdtner, 1991; Cowan, 1996; Riller and Schwerdtner, 1997; Riller, 2005). Here, the derived 3D geologic model and forward computation were used to evaluate these hypotheses and present a new geophysical interpretation of the development of structures at the base of the Sudbury Structure.

\section{Testing of basal deformation}

The hypothesis proposed to explain the linear high gravity anomaly under the Sudbury Basin, that is, the northward folding of the basal SIC rocks, is consistent with the known pre- and postimpact geologic history of the Sudbury area. Other possible geologic models to explain the high gravity trend were considered, including proposed hidden layered mafic/ultramafic intrusions as suggested by Gupta et al. (1994). Small bodies of mafic intrusions such as Chicago (at the junction of the south and north ranges), Norduna (at the junction of the east and south ranges), and Joe Lake in the north range occur around the SIC. We suggest that the event that deformed the SIC is more probably a late Proterozoic Penokean deformation because it is interpreted to have affected the basal part of the SIC and the transitional zone. The ages of these small mafic plutons around the SIC predate the emplacement of the SIC. A recent study indicates the Joe Lake intrusion to be Archean in age (2657 $\pm 9 \mathrm{Ma}$, Ames et al., 2013), and Norduna is dated at $2450 \mathrm{Ma}$ (Prevec, 1993). Therefore, mafic rock preexisting at the target site of the meteorite impact would probably have been highly brecciated and melted in the crater, and it might not have resulted in folding or any kind of deformation at the basal part of the SIC. Also, a mafic intrusive event after the SIC emplacement will probably have intruded fault zones and result in intrusive contacts such as olivine diabase, rather than folding. Last, this kind of intrusion would have probably been more restrained in size, causing a circular or ovalshaped gravity response and not a $42-\mathrm{km}$ linear gravity high in the Sudbury Basin.

Basement thick-skinned deformation resulting in thrusting and uplift of the basement (Olaniyan et al., 2014) was also tested using a 3D forward modeling approach. This can be modeled by changing the density $\left(2.80-2.83 \mathrm{~g} / \mathrm{cm}^{3}\right.$ ) of block A (Figure $\left.3.4 \mathrm{~b}\right)$ at the basal part of the SIC to the Archean basement density $\left(2.73 \mathrm{~g} / \mathrm{cm}^{3}\right.$, Gupta et al., 1994), whereas every other 
parameter remains the same. The resulting test grid should also further isolate the gravity response due to the relatively dense Onaping Formation $\left(2.77 \mathrm{~g} / \mathrm{cm}^{3}\right)$ and also evaluate the influence of other deep-seated dense sources on the gravity field in the Sudbury basin. This rapidly computed 3D forward gravity response (Figure 12) is devoid of the long-wavelength gravity high that is observed within the Sudbury Basin (Figure 11), which also extends to the footwall of the south range over the Huronian metasediments. Likewise, it shows that the gravity response due to the Onaping Formation is limited and sits on a broader anomaly. The result of the $3 \mathrm{D}$ forward modeling clearly illustrates the existence of a deeper dense source under the Huronian metasedimentary rocks, which further extends to the north and gets shallower under the southern part of the Sudbury Basin (Figure 13).

\section{Timing and implication of the basal deformation}

Recent reconstructions of the predeformation geometry of the SIC suggest that it had an initial circular geometry with a minimum diameter of $60 \mathrm{~km}$ and was differentiated from a melt sheet of approximately $2.5 \mathrm{~km}$ thickness (Roest and Pilkington, 1994). Due to its large crater size, the thickness of the melt sheet $(\sim 2.5 \mathrm{~km})$, and the postimpact breccias and deposits $(\sim 3 \mathrm{~km})$, it was suggested that and the differentiation process would have lasted up to 500 million years (Grieve et al., 1991; Ivanov and Deutsch, 1999), allowing for multiple, synemplacement modifications. A more recent study at the Garson Mine on the south range argued that Penokean deformation in the Sudbury area started shortly after the emplacement of the SIC (Mukwakwami et al., 2014). Either way, the compressive Penokean regime was northwest-directed and resulted in the compressive tectonic structures observed in the south range of the SIC (Shanks and Schwerdtner, 1991).

The suggestion that deformation at the base of the SIC contributed to its present postimpact shape only requires simple changes to present interpretations of the postimpact deformation of the Sudbury Structure. Our model proposes that some geologic features observed within the SIC, such as in-basin northeast open folds and the longitudinal south-dipping Vermilion Fault set, have deep-seated origins. The model is consistent with postimpact Penokian inversion of preimpact Huronian rift basins along the continental margin of the superior craton. Postimpact reverse movement along the syndepositional Murray Fault set has been reported by Raharimahefa et al. (2014). Simplified geologic

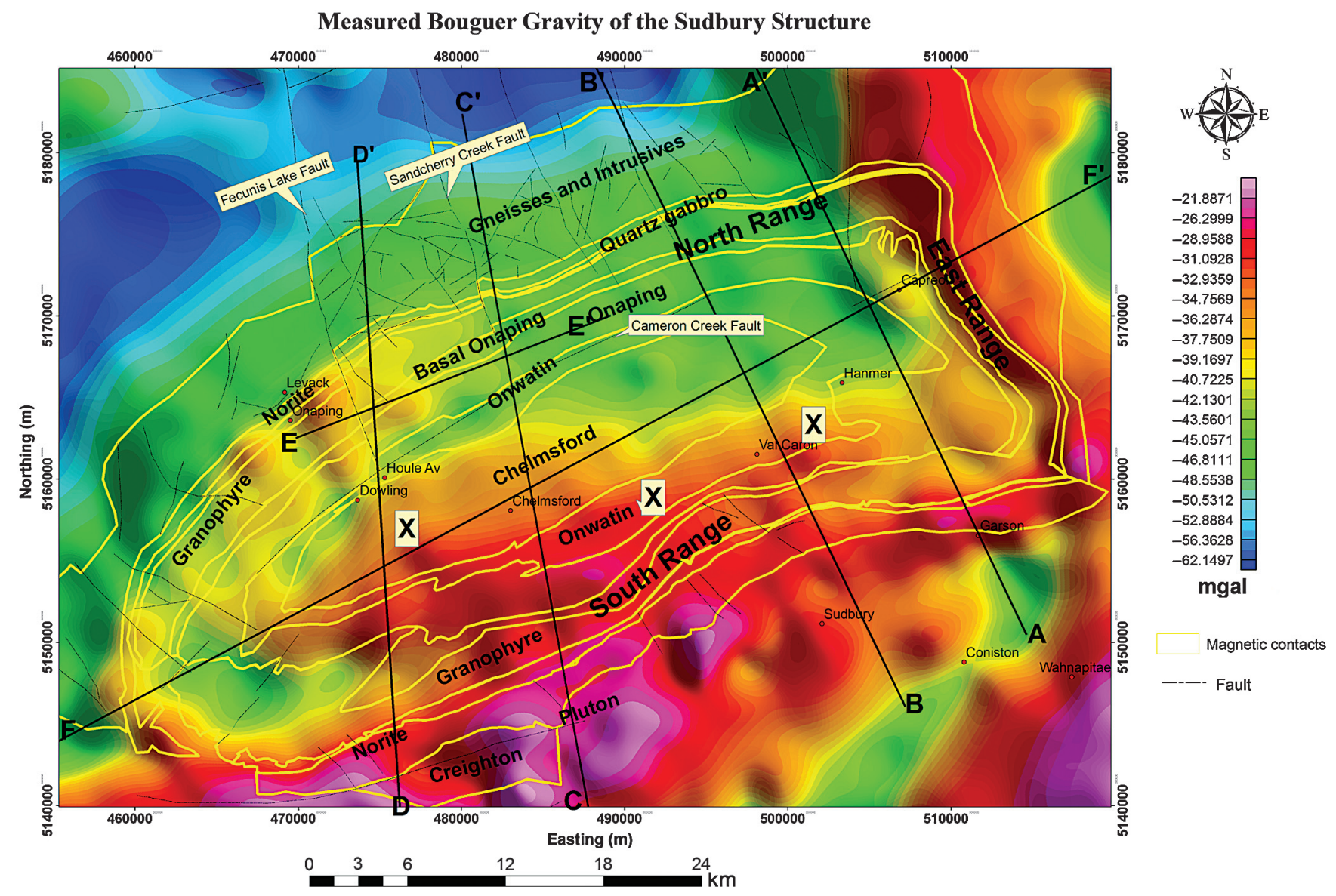

Figure 11. Measured free-air gravity anomaly of the Sudbury Structure. 
Calculated gravity gravity field of the Sudbury structure (Test)

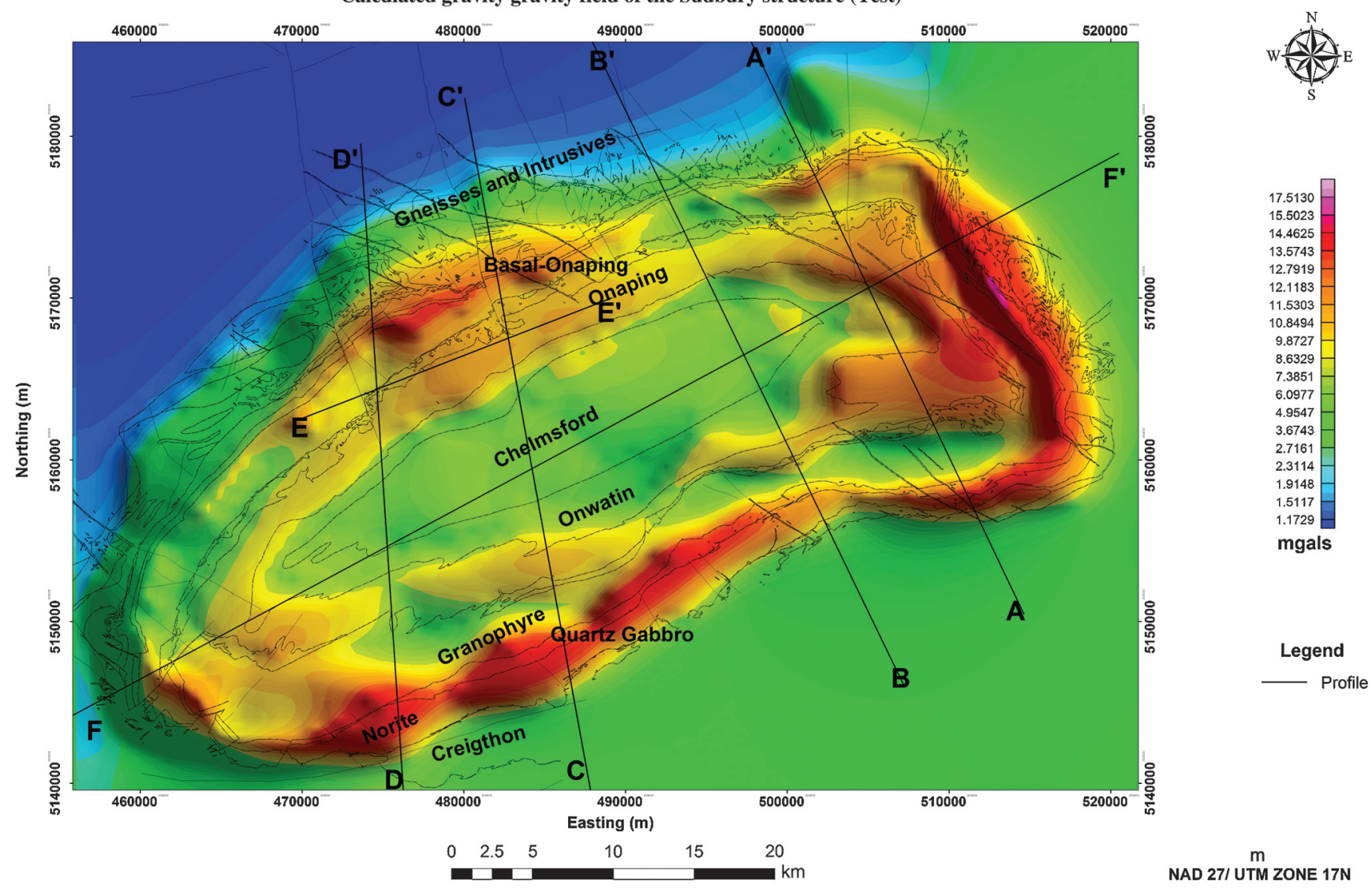

Figure 12. Test grid of the forward gravity response assuming that the density of the wedge is same as the density of the basement $2.73 \mathrm{~g} / \mathrm{cm}$.

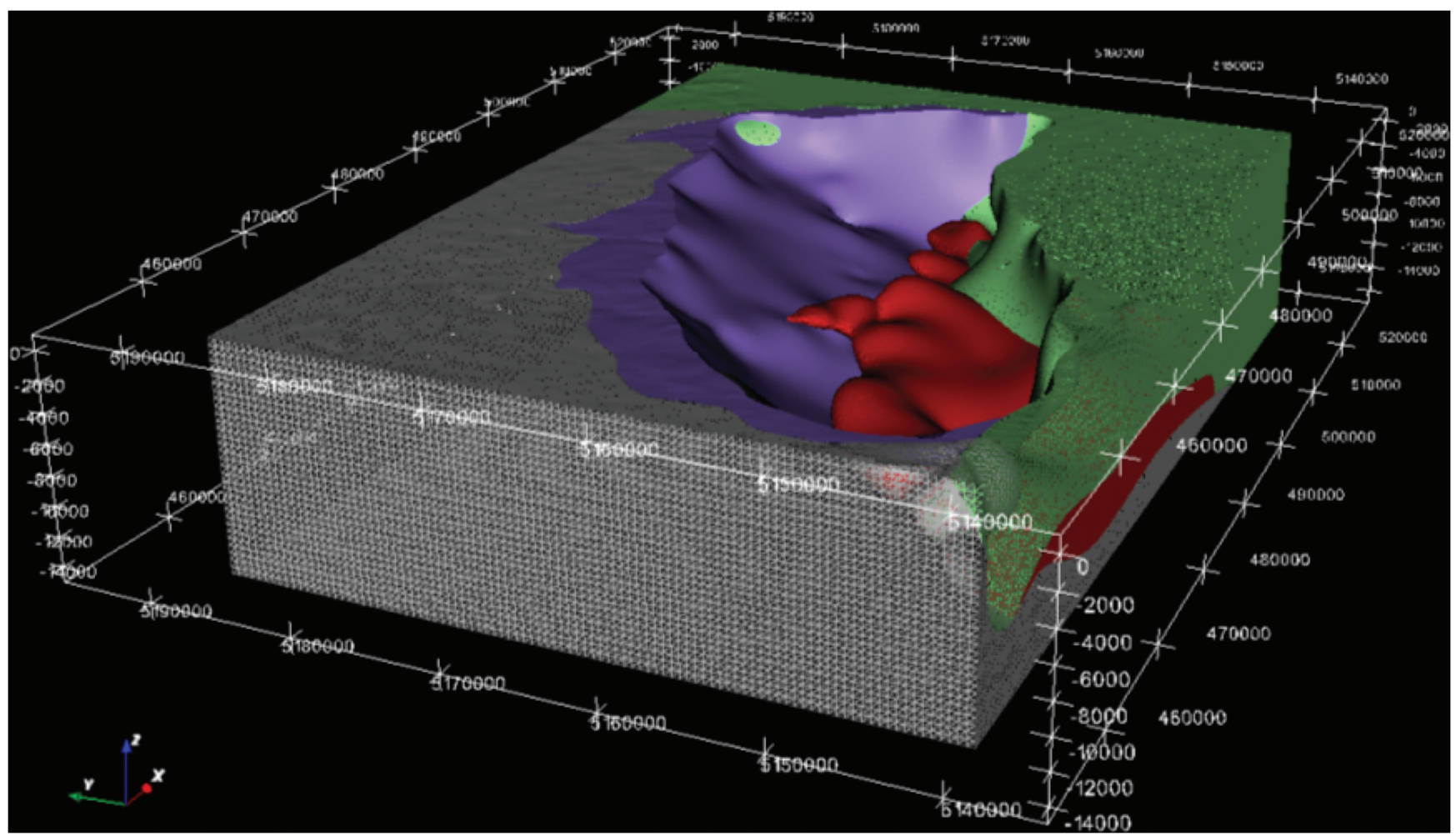

Figure 13. Wire-frame 3D geologic model of the Sudbury Structure illustrating the occurrence of the thrusted Elliot Lake mafic volcanics and other intrusions at the base of the SIC (not shown) in the south range. 
cross-section diagrams are used to illustrate how the normal faults bounding the Huronian rift margin basins could have been reactivated as reverse faults that de- formed the basal part of the SIC. The proposed sequence of events (A-F) is presented in Figure 14 below and described as follows: a)

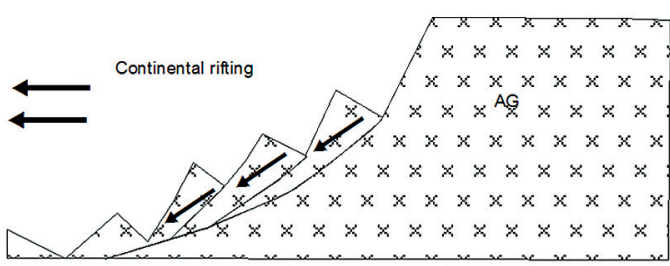

b)

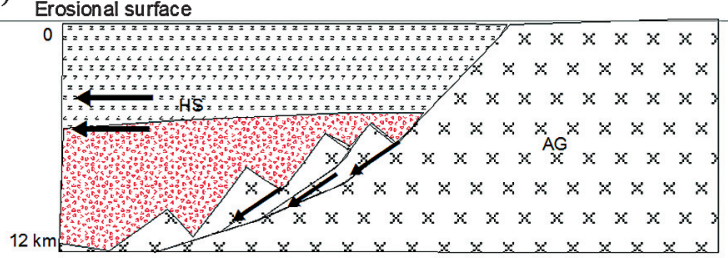

Proposed deformational sequence of the Sudbury structure (Cartoon, not to scale).

1) Development of the Huronian continental rift margin along the boundary of the superior and the Southern Provinces c)

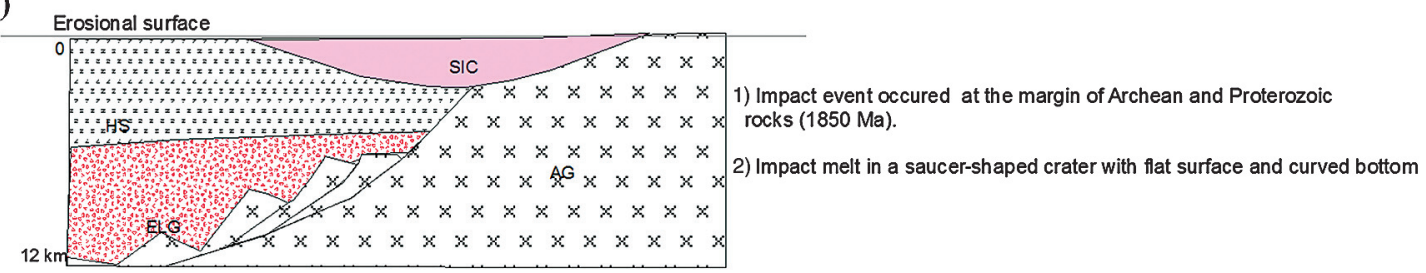

\section{1) Continental rifting continues \\ 2) Emplacement of the Huronian volcanics and sedimentary rocks ( 2.4 to $2.2 \mathrm{Ga}$ ) \\ 3) Intrusion of Huronian rocks by Murray ( $2.4 \mathrm{Ga}$ ) and Creigthon (2.3 Ga) and Nippissing diabase $(2.2 \mathrm{Ga})$ ( not shown) \\ 4) Transition from rift margin to passive margin and sinistral movement}

d)

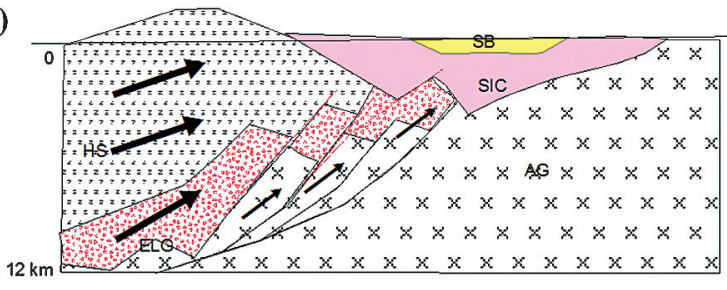

e)

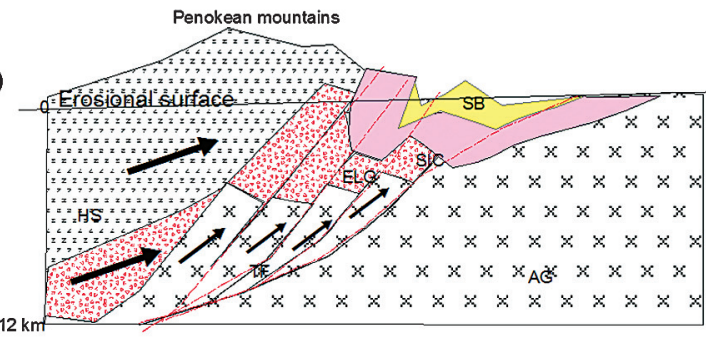

1) Volcanic activities and explosive interaction of magma with water led to deposition of the Onaping Formation and Onwatin Formation was later deposited in a more quiescent environment.

2) Post-SIC Penokean orogeny began shortly after the impact melt has differentiated.

3) Transition from passive margin into foreland margin system

4) Northward thrusting of the basal Huronian mafic rocks and other mafic intrusive rocks.

5) Deformation of the basal portion of the SIC

6) Development of a north-vergent fold at the base of the SIC

Further compressional deformation during the Penokean orogeny might have resulted into:

1) deformation of the initial geometry of the SIC

2) tigthening of the open folds.

3) overturning of the SIC in the south range

4) development of fractures and joints in the northwest direction.

5) Development of Penokean mountains and deposition of the Chelmsford Formation

6) thrusting of the Elliot Lake northward to south of the SIC and the felsic plutons

(F)

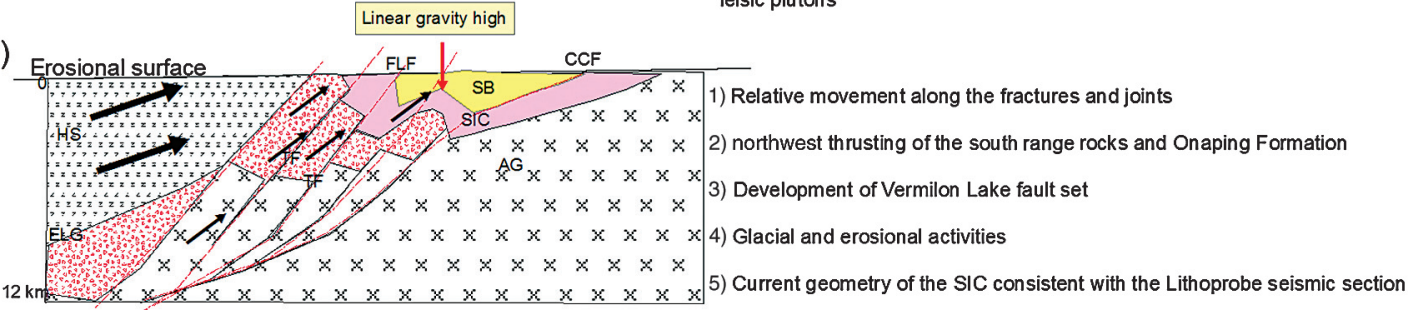

Figure 14. Proposed timing and sequence of the deformation of the Sudbury Structure. 
1) The development of the Huronian continental rift margin likely to have been initiated by an impinging hot spot (Heaman, 1997) or in response to the tensional force in crust and lithospheric mantle (Dunbar and Sawyer, 1988).

2) Deposition of supracrustal rocks during rifting began with conglomerates of the Livingstone Creek Formation and uranium-rich Matinenda Formation of the Elliot Lake Group. In the Sudbury region, a thick package of volcanic rocks interbedded with minor stratified metasedimentary rocks (Elsie Mountain, Stobie, and Copper Cliff Formations) was emplaced early during rifting. These volcanic rocks underlie a 12-km-thick sequence of Huronian sedimentary rocks that was deposited as the superior margin evolved from a rifted margin to a stable continental margin (Long and Lloyd, 1983; Young et al., 2001). Although not illustrated in the cartoon, the Huronian rocks were intruded by the felsic plutons Murray (2477 Ma, Krogh et al., 1996) and Creighton (2333 Ma, Frarey et al., 1982) as well as the Nipissing diabase sills and dikes (2219 Ga, Corfu and Andrews, 1986).

3) At $1850 \mathrm{Ma}$, an extraterrestrial bolide collided with superior continental margin. Our model assumes that the SIC was initially $2.5 \mathrm{~km}$ thick and was circular with a minimum $65-\mathrm{km}$ diameter (Roest and Pilkington, 1994). The Onaping and Onwatin Formations were deposited in the depression formed by the crater, which sits on gently south-dipping Archean gneisses that are covered to the south by a southward thickening sequence of Huronian sedimentary rocks (Milkereit and Green, 1992).

4) The postimpact, northwest-directed, Penokean Orogeny reactivated normal faults below the Huronian sequence as reverse faults thereby thrusting the faulted basement and the Elliot Lake group mafic volcanic rocks northward below the SIC. A Penokean mountain chain formed that shed sediments of the Chelmsford Formation into the Sudbury Basin, overlying the SIC and impact-related breccias of the Onaping Formation (Young et al., 2001). The SIC norite acted as a competent mechanical anisotropy (Boerner and Milkereit, 1999) that buckled during deformation resulting in the formation of a northverging ductile fold at the base of the SIC. This resulted in the formation of broad open anticlinal and synclinal folds in the Sudbury Basin (Shanks and Schwerdtner, 1991). The north limb of the anticlinal structure corresponds to the north-dipping reflectors in the Lithoprobe section under the Sudbury Basin.

5) Continued shortening during the Penokean deformed the SIC into its present elliptical shape (Grieve et al., 1991; Milkereit and Green, 1992; Deutsch et al., 1995; Wu et al., 1995) and resulted into the tightening of the folds in the Sudbury Basin, overturning of the SIC-basement contact in the south range, and formation of thrust faults in the south range and Sudbury Basin.

6) Erosional activity reduced the elevated part of the south range to the current level. This current state of the SIC explains most of the reflectors interpreted in the Lithoprobe transect (Olaniyan et al., 2014).

\section{Mineral resource potential of the 3D models}

The possibility of deep-contact sulfide deposits at the depth of 4 to $6 \mathrm{~km}$ was highlighted in a previous paper (Olaniyan et al., 2014). Our 3D geologic forward modeling further constrains the possible sources of the linear gravity high below the Sudbury Structure. However, the calculated broad linear anomaly at $4-5 \mathrm{~km}$ is less strong than the observed anomaly (Figure 10). This could imply that the folded portion of the SIC rocks is shallower under the Sudbury Basin, or it is due to the presence of the xenolith-bearing sublayer; both cases are of mineral exploration interest.

\section{Conclusions}

Our proposed 3D geologic model, which is based on prior geologic knowledge, a seismic section, and available potential field data, has provided insights into the sources of previously unexplained geophysical anomalies in the Sudbury Structure. The linear gravity high under the Sudbury Basin is related to the north-verging folding and deformation at the base of the SIC due to the reversal of normal faults as reverse faults that thrust Huronian mafic volcanic rocks below the SIC. Having developed a 3D model for the Sudbury Structure, this model can continually be updated as more detailed subsurface information, such as more reflection seismic data across the SIC and/or drilling a deep borehole, becomes available.

\section{Acknowledgments}

Our thanks go to NSERC, Vale, Sudbury Integrated Nickel Operations, KGHM International, Wallbridge Mining, and the Centre for Excellence in Mining Innovation for providing data and financial support.

\section{References}

Ames, D. E., A. J. Davidson, L. Buckle, and K. D. Card, 2005, Geology, Sudbury bedrock compilation, Ontario: Geological Survey of Canada, Open file 4570, Scale 1:50000.

Ames, D. E., and C. E. G. Farrow, 2007, Metallogeny of the Sudbury mining camp, Ontario, in W. D. Goodfellow, ed., Mineral deposits of Canada: A synthesis of major deposit-types, district metallogeny, the evolution of geological provinces, and exploration methods: Geological Association of Canada, Mineral Deposits Division, Special publication 5, 329-350.

Ames, D. E., J. J. Hanley, G. Tuba, W. Bleeker, and S. Kamo, 2013, Primitive source revealed in the Sudbury impact structure: Implications for cratering and metal sources: 
Presented at Large Meteorite Impacts and Planetary Evolution V Meeting 3099.

Boerner, D. E., and B. Milkereit, 1999, Structural evolution of the Sudbury impact structure in the light of seismic reflection data, in B. O. Dressler, and V. L. Sharpton, eds., Impact cratering and planetary evolution II: Geological Society of America, Special paper 339, 419-430.

Card, K. D., 1965, Geology of the Hyman and Drury Townships: Ontario Department of Mines, Geological report.

Card, K. D., and S. L. Jackson, 1995, Tectonics and metallogeny of the Early Proterozoic Huronian foldbelt and the Sudbury Structure of the Canadian shield, field trip guide book: Geological Survey of Canada, Open file 3139.

Caumon, G., P. Collon-Drouaillet, C. Le Carlier de Veslud, S. Viseur, and J. Sausse, 2009, Surface-based 3D modeling of geological structures: Mathematical Geosciences, 41, 927-945.

Corfu, F., and A. Andrews, 1986, A U-Pb age for mineralized Nipissing diabase Gowganda, Ontario: Canadian Journal of Earth Sciences, 23, 107-109, doi: 10.1139/ e86-011.

Cowan, E. J., 1996, Deformation of the eastern Sudbury Basin: Ph.D. thesis, University of Toronto.

Deutsch, A., R. A. F. Grieve, M. Avermann, L. Bischoff, B. Brockmeyer, D. Buhl, R. Lakoomy, R. Muller-Mohr, M. Ostermann, and D. Stoffer, 1995, The Sudbury Structure (Ontario, Canada): A tectonically multi ring impact basin: Geologische Rundschau, 84, 697-709, doi: 10.1007/ s005310050034.

Dietz, R. S., 1964, Sudbury Structure as an astrobleme: Journal of Geology, 72, 412-434, doi: 10.1086/626999.

Dressler, B. O., 1984, General geology of the Sudbury area, in E. G. Pye, A. J. Naldrett, and P. E. Giblin, eds., The geology and ore deposit of the Sudbury Structure: Ontario Geological Survey 1 57-82.

Dunbar, J. A., and D. S. Sawyer, 1988, Continental rifting at pre-existing lithospheric pressure weaknesses: Nature, 333, 450-452, doi: 10.1038/333450a0.

Frarey, M. J., W. D. Loveridge, and R. W. Sullivian, 1982, A U-PB age for the Creighton granite, Ontario, in $\mathrm{Rb}-\mathrm{Sr}$ and U-Pb isotope age studies, Report 5, current research, Part C: Geological Survey of Canada 82, 129-132.

Galdeano, A., M. A. G. Andreoli, and R. J. Hart, 2008, Magnetic imaging of the Vredefort Dome: Implications for the size and geometry of the Vredefort Crater, in $\mathrm{B}$. O. Dressler, and V. L. Sharpton, eds., Large Meteorite Impacts and Planetary Evolution IV: Geological Society of America.

Grieve, R. A. F., D. Stoffler, and A. Deutsch, 1991, The Sudbury Structure: Controversial and misunderstood?: Journal of Geophysical Research, 96, 22753-22764, doi: 10.1029/91JE02513.

Gupta, V. K., F. S. Grant, and K. D. Card, 1994, Gravity and magnetic characteristics of the Sudbury structure, in E. G. Pye, A. J. Naldrett, and P. E. Giblin, eds., The geol- ogy and ore deposits of the Sudbury Structure: Ontario Geological Survey 1, 381-410.

Heaman, L. M., 1997, Global mafic magmatism at 2.45 Ga: Remnants of a large igneous province: Geology, 25, 295298, doi: 10.1130/0091-7613(1997)025<0299:GMMAGR>2 .3.CO;2.

Hearst, R. B., and W. A. Morris, 2001, Regional gravity setting of the Sudbury Structure: Geophysics, 66, 16801690, doi: $10.1190 / 1.1487110$.

Hearst, R. B., W. A. Morris, and M. D. Thomas, 1994, Magnetic interpretation along the Sudbury Structure Lithoprobe transect, in P. C. Lightfoot, and A. J. Naldrett, eds., Proceedings of the Sudbury-Noril'sk Symposium: Ontario Geological Survey 5, 33-43.

Ivanov, B. A., and A. Deutsch, 1999, Sudbury impact event: Cratering mechanics and thermal history, in B. O. Dressler, and V. L. Sharpton, eds., Large meteorite impacts and planetary evolution II: Geological Society of America, Special paper 339, 389-397.

Krogh, A., 1997, Shock metamorphosed zircons with correlated U-Pb discordance and melt rocks with concordant protolith ages indicate an impact origin for the Sudbury structures, in A. Basu, and S. Hart, eds., Earth processes: reading the isotope code: American Geophysical Union Monograph.

Lajaunie, C., G. Courrioux, and L. Manuel, 1997, Foliation fields and 3-D cartography in geology: Principles of a method based on potential interpolation: Mathematical Geology, 29, 571-584, doi: 10.1007/BF02775087.

Lane, R., and A. Guillen, 2005, Geologically-inspired constraints for a potential field litho-inversion scheme, in Q. Cheng, and G. F. Bonham-Carter, eds., Proceedings of IAMG'05: GIS and Spatial Analysis: International Association of Mathematical Geology 1, 181-186.

Long, D. G. F., and T. R. Lloyd, 1983, Placer gold potential of basal Huronian of the Elliot Lake Group in the Sudbury Area, Ontario, in J. Wood, O. L. White, R. B. Barlow, and A. C. Colvine, eds., Part A: Ontario Geological Survey, Miscellaneous paper 126 256-258.

McGrath, P. H., and H. J. Broome, 1994, A gravity model of the Sudbury Structure along the Lithoprobe seismic line: Geophysical Research Letters, 21, 955-958, doi: 10.1029/93GL02247.

McInerney, P., A. Guillen, G. Courrioux, P. Calcagno, and T. Lees, 2005, Building 3-D geological models directly from data? A new approach applied to Broken Hill, Australia: Presented at Digital Mapping Techniques 2005 Workshop.

Milkereit, B., and A. Green, Sudbury working group, 1992, Deep geometry of the Sudbury Structure from seismic reflection profiling: Geology, 20, 807-811, doi: 10.1130/ 0091-7613(1992)020<0807:DGOTSS>2.3.CO;2.

Mukwakwami, J., B. Lafrance, C. M. Lesher, D. K. Tinkham, N. M. Rayner, and D. E. Ames, 2014, Deformation, metamorphism and mobilisation of Ni-Cu-PGE sulfide ores at Garson Mine, Sudbury: Mineralium Deposita, 49, 175198, doi: 10.1007/s00126-013-0479-y. 
Naldrett, A. J., J. G. Bray, E. L. Gasparrini, T. Podolsky, and J. C. Rucklidge, 1970, Cryptic variations and the petrology of the Sudbury Nickel Irruptive: Economic Geology, 65, 122-155, doi: 10.2113/gsecongeo.65.2.122.

Olaniyan, O. F., R. S. Smith, and B. Lafrance, 2014, A constrained potential field data interpretation of the deep geometry of the Sudbury Structure: Canadian Journal of Earth Sciences, 51, 715-729, doi: 10.1139/cjes-20130212.

Olaniyan, O. F., R. S. Smith, and W. M. Morris, 2013, Qualitative interpretation of the Sudbury Structure: Interpretation, 1, no. 1, T25-T43, doi: 10.1190/INT-20120010.1 .

Pilkington, M., and R. A. F. Grieve, 1992, The geophysical signature of terrestrial impact craters: Review of Geophysics, 30, 161-181, doi: 10.1029/92RG00192.

Polzer, B., 2000, The role of borehole EM in the discovery and definition of the Kelly Lake Ni-Cu deposit, Sudbury, Canada: 70th Annual International Meeting, SEG, Expanded Abstracts, 1063-1066.

Prevec, S. A., 1993, An isotopic, geomechanical and petrographic investigation of genesis of early Proterozoic mafic intrusion and associated volcanism near Sudbury, Ontario: Ph.D. thesis, University of Alberta.

Pye, E. G., A. J. Naldrett, and P. G. Giblin, 1984, The geology and ore deposits of the Sudbury Structure: Ontario Geological Survey 1.

Raharimahefa, T., B. Lafrance, and D.K. Tinkham, 2014, New Structural, metamorphic and U-Pb geochronological evolution of the Southern Province, Sudbury, Canada: Canadian Journal of Earth Science, 51, 750-774, doi: 10.1139/cjes-2014-0025.

Riller, U., 2005, Structural characteristics of the Sudbury impact structure, Canada: Impact induced and orogenic deformation: Meteoritics and Planetary Science, 40, 1723-1740, doi: 10.1111/j.1945-5100.2005 .tb00140.x.

Riller, U., and W. M. Schwerdtner, 1997, Mid-crustal deformation of the southern flank of the Sudbury Basin, central Ontario, Canada: Geological Society of America Bulletin, 109, 841-854, doi: 10.1130/0016-7606(1997) $109<0841$ :MCDATS > 2.3.CO;2.
Roest, W. R., and M. Pilkington, 1994, Restoring post-impact deformation at Sudbury: A circular argument: Geophysical Research Letters, 21, 959-962, doi: 10.1029/ 93GL02044.

Rousell, D. H., 1984, Onwatin and Chelmsford Formations, in E. G. Pye, A. J. Naldrett, and P. E. Giblin, eds., The geology and ore deposit of the Sudbury Structure: Ontario Geological Survey 1, 211-218.

Shanks, W. S., and W. M. Schwerdtner, 1991, Structural analysis of the central and southwestern Sudbury Structure, Southern Province, Canadian Shield: Canadian Journal of Earth Sciences, 28, 411-430, doi: 10.1139/ e91-037.

Spray, J. G., H. R. Butler, and L. M. Thompson, 2004, Tectonic influences on the morphometry of the Sudbury impact structure: Implication for terrestrial cratering and modeling: Meteoritics and Planetary Science, 39, 287301, doi: 10.1111/j.1945-5100.2004.tb00341.x.

Veermeesch, P. M., and J. V. Morgan, 2008, Structural uplift beneath the Chicxulub impact structure: Journal of Geophysical Research, 113, B07103, doi: 10.1029/ 2007JB005393.

Watts, A., 1997, Exploring for nickel in the 90s, or "Til depth us do part", in A. G. Gubins, ed., Proceedings of Exploration 97: Fourth Decennial International Conference on Mineral Exploration: Prospectors and Developers Association.

Williams, C. N., 2006, Applying UBC-GIF potential field inversions in greenfields or brownfields exploration: Presented at Australian Earth Sciences Convention, AESC2006.

Wu, J., B. Milkereit, and D. Boerner, 1995, Seismic imaging of the enigmatic Sudbury Structure: Journal of Geophysical Research, 100, 4117-4130, doi: 10.1029/ 94JB02647.

Young, G.M., D.G.F. Long, C.M. Fedo, and H.W. Nebitt, 2001, The paleoproterozoic wilson cycle in the Great Lakes region: The Canadian Mineralogist, 33, 265-301.

Biographies and photographs of the authors are not available. 